\title{
Observações hidrobiológicas na cisterna da Ilha do Pinheiro
}

\author{
por \\ Lejeune $\mathbf{P}$. H. de Oliveira \\ Encarregado da Estação de Hidrobiologia \\ Luiza Krau \\ Assistente da Estação de Hidrobiologia
}

\author{
Rubem do Nascimento \\ da Divisâo de Química e Farmacologia
}

(com 14 figuras)

A cisterna em estudo fica na parte sul da Ilha do Pinheiro, no recôncavo oeste da Baía de Guanabara, defronte a Praia de Inhauma da Cidade do Rio de Janeiro. Ela se acha na posição apresentada pelo mapa da figura 1. Está a 90 metros da Praia dos Macacos banhada pela semi-salobra Enseada de Inhauma. Ao lado da cisterna houve um antigo Nicho do Jesuíta, hoje em ruínas, a pé deste começa o morro do Pinheiro que vai em rampa forte até aos prédios da Estação de Hidrobiologia do Instituto Oswaldo Cruz localisados a 24 metros de altitude.

A soleira da cisterna está na altitude de $3,52 \mathrm{~m}$., sua boca tem $2,26 \mathrm{~m}$. de diâmetro, sua parede lateral perfeitamente cilíndrica é obra de antiga cantaria, feita em granito que recobre até a profundidade de $4 \mathrm{~m}$. A figura 3 representa um corte desta cisterna. Conforme explica a figura 2: a Praia dos Macacos (moderno nome devido a criação de Macaccus rhezus em liberdade existentes nesta ilha) é banhada pelas águas da Enseada de Inhauma cuja salinidade varia de 27 até 33 por mil, e há um mangrove com as árvores do mangue Rhizophora mangle, Avicennia tomentosa, Laguncularia racemosa depois seguido de uma restinga que se enche e se esvazia permanentemente, alternando com as marés.

Habita em seu interior barrento e salobro uma população de carangueijinhos chama-maré Uca pugnax e mais para dentro ha bura$\cos$ dos grandes guaiamús Cardisoma guanhumi em terra mais consistente. Desta restinga, do local onde houve uma comporta, a comporta "Nogueira Penido", hoje um sangradouro, até ao local da cisterna vão 100 metros, tomados em linha reta. A cisterna foi cavada em terra vermelha, não arenosa, em terreno de barreira terciário. No correspondente á terra húmida, e na parte mais clara o que é terra sêca, não empapada de água. A vizinhança do mar confere um certo 
grau de infiltração pelas águas da Baía de Guanabara. Esta infiltração geralmente só influe no fundo: aí ficam as águas mais salobras quando em repouso longo, devido a sua densidade maior não tornando as águas mais leves, densidade $=1,0037$, superficiais, mais salobras. Uma grande mangueira e um pé de jamelão fazem sombra ás águas dêste poço e nele deixam cair sua fôlha desde 1938 .

Uma das razões pelas quais este poço foi escolhido para estudo é ser consagrado ao exercício prático dos estudantes de hidrobiologia feito junto á parte teórica do curso ministrado no Laboratório de Hidrobiologia.

Prevenimos que entre as dificuldades ao estudar biològicamente uma massa de água encontram-se sobretuđo as pertubações artificiais decorrentes do uso do poço pelo povo quando vai retirando a água. Realisa-se assim um remexer contínuo e ha sempre uma massa de água retirada e ha outra nova entrada de origem telurica, de modo que pouco o hidrobiologista poderá decidir sobre tal ciclo. Evitamos suficientemente tais causas de êrro pela escolha desta cisterna, que está abandonada, e que foi cavada ha mais de um século pelos antigos moradores da ilha do Pinheiro; hoje ninguém nela toca a não ser os técnicos para seus estudos e observações.

Anteriormente a 1938 a água deste poço era doce e relativamente potável, foi usada para irrigar as hortas que haviam na ilha. Houve em 1938 uma limpeza. Esta limpeza foi possível, segundo contou-nos o vigía da Ilha do Pinheiro, no período de grande sêca e foi feita pelo Sr. DaRIo LOPES, antigo pescador do Instituto Oswaldo Cruz, residente na ilha até ao dia de sua morte. O nível deveria estar a $1 \mathrm{~m}$. acima do fundo atual, era todo de fôlhas sêcas, e nesta ocasião cavaram em sêco até ao nível de 50 centímetros abaixo do nível médio do mar, que é o fundo marcado na cota de $4 \mathrm{~m}$. da régua limnográfica (fig. 3).

No tempo de uma grande enchente, em 1940, quando houve uma inundação em que todos os trilhos da Estrada de Ferro Leopoldina Railway da zona suburbana de Manguinhos e de Bonsucesso ficaram debaixo dágua, esta cisterna soltava suas águas doces a grande vazão pelas bordas, a $3,42 \mathrm{~m}$. Com efeito concebe-se que ela deverá se comunicar com o lençol de água subterrânea que a alimenta, em terreno possivelmente terciário de barro vermelho, e êste deve passar por baixo da Enseada de Inhauma da qual deverá ser isolado por uma camada geológica impermeável ou mesmo pela argila preta impermeável do fundo da enseada. Resulta desta exposição o fato de que se o nível estêve por vêzes muito abaixo, por vêzes muito acima, do nível médio do mar, não devendo haver uma comunicação direta com o mar. Como as vêzes fica ligeiramente salobra, a explicação que podemos dar é a seguinte: nos dias de sêca ha uma retenção de sais no manguesal pelas águas de preamar que o cobrem e evaporam; depois a chuva lavando-as leva uma certa quantidade de sais para as águas subterrâneas que vão alimentar a cisterna. Nos dias em que suas águas estiveram acima do nível médio do mar, em 1940, ela se limpou muito, por efeito de transbordamento, e segundo os antigas moradores da ilha a água ficou òtimamente potável por 


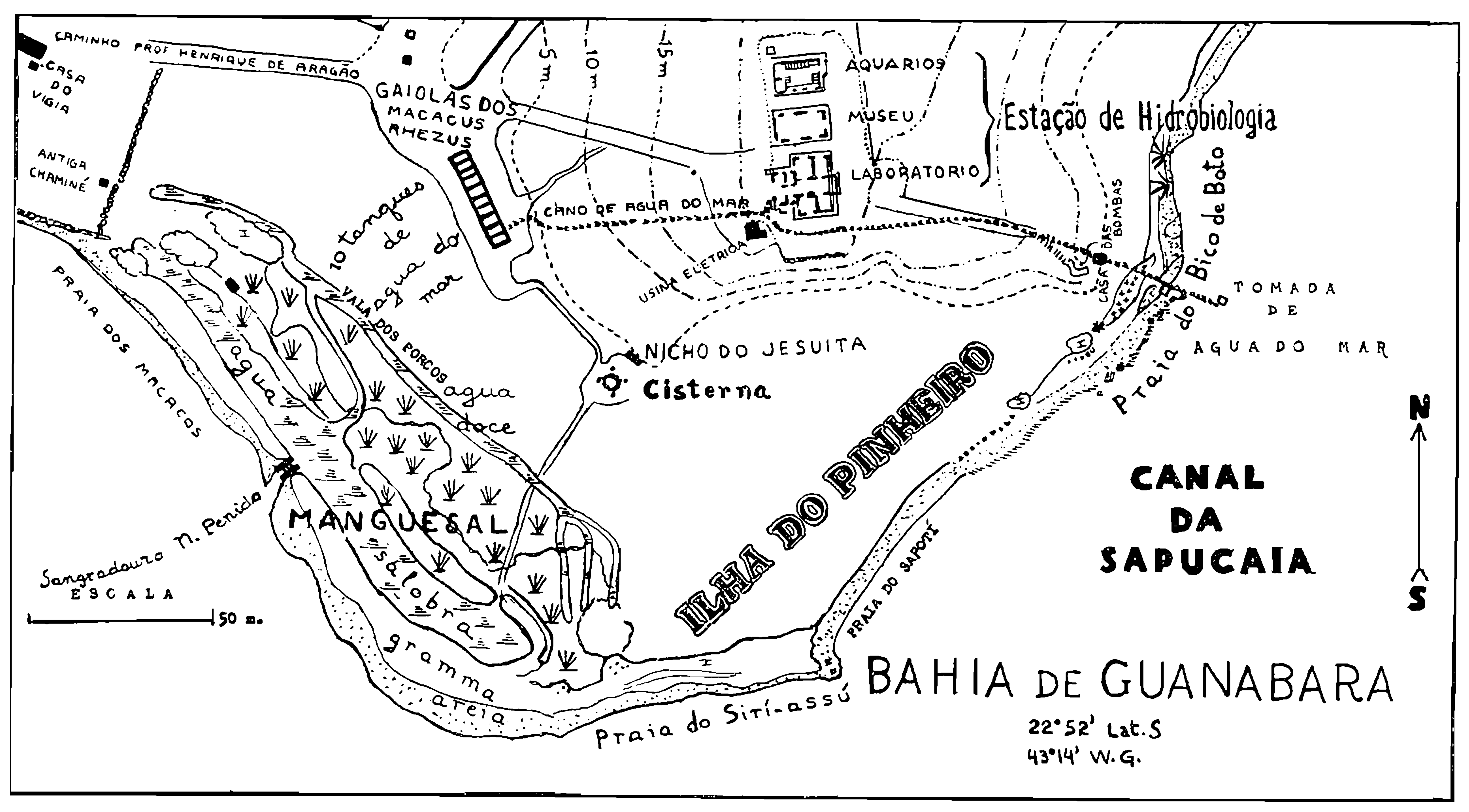

Figura 1 - Parte sul da Ilha do Pinheiro, extraída da planta levantada por Lejeune de Oliveira para o próximo trabalho a aparecer em breve: "Sôbre o crescimento do manguesal em 50 anos na Ilha do Pinheiro". 
cêrca de um ano; também as abundantes chuvas lavaram todos os sais nas terras permeáveis dos manguesais.

Laboratorio

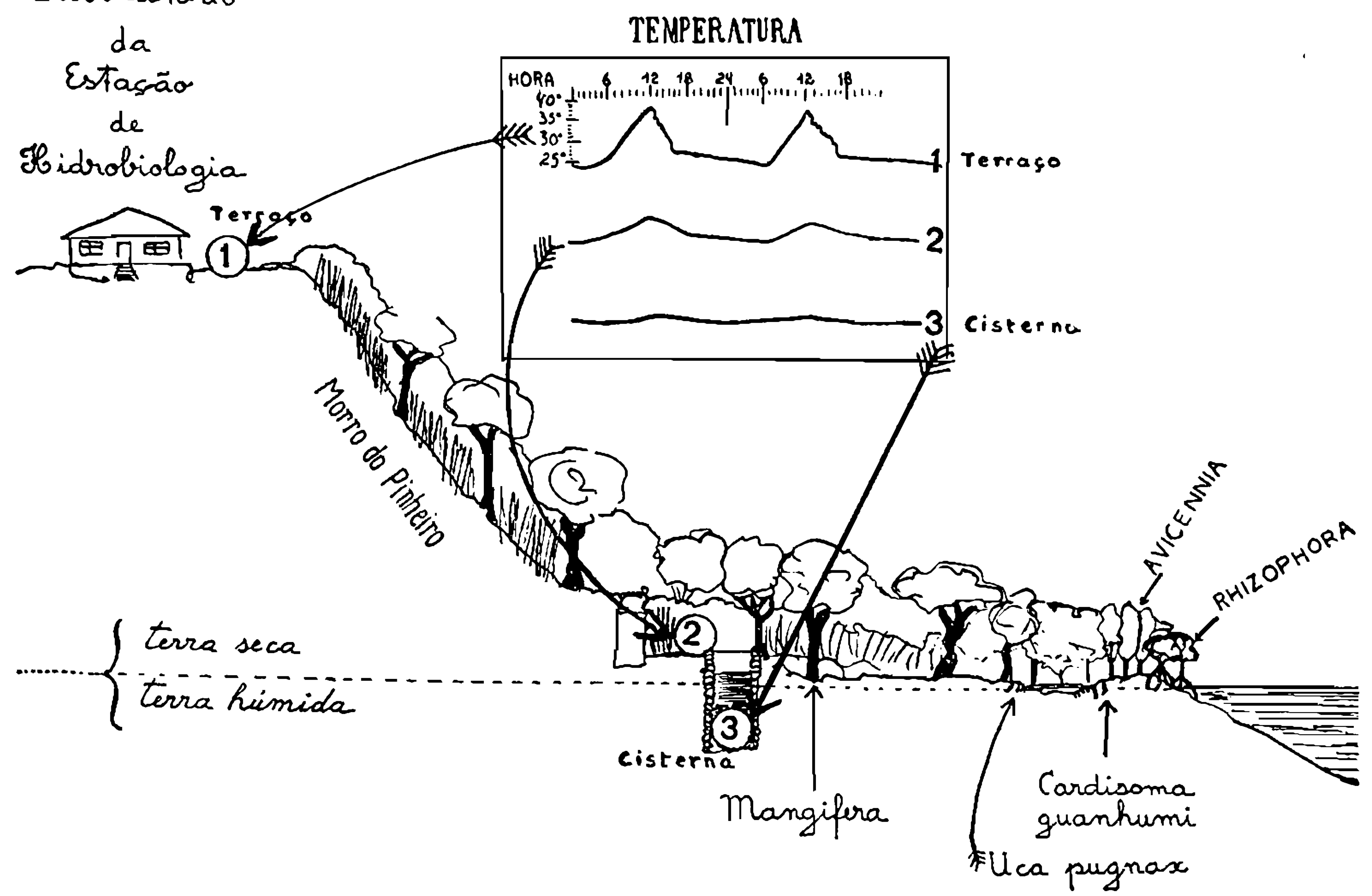

Figura 2 - Uma esquema mostrando um perfil desde á Práia dos Macacos até ao Laboratório de Hidrobiologia, passando pela cisterna. Sugerimos no esquema as diferenças de temperatura do ar, e a constância da temperatura da água da cisterna. Vê-se junto ao mar o manguesal com as árvores de mangue Rhizophona, Avicennia, e os buracos dos guaiamús Cardisoma guanhumi e dos chama-marés Uca pugnax. A o pé da cisterna uma mangueira Mangífera.

Lembremo-nos que foi em 1944, quando o Prof. Dr. HeNRIQUe DE ARAGÀo era diretor do Instituto Oswaldo Cruz, que êle mandou colocar uns peixinhos Lebistes reticulatus e algumas plantas popularmente chamadas de elodeas, (as Anacharis canadensis) dentro da cisterna.

A primeira análise química feita em 28 de agôsto de 1950 pelo Dr. RUBEM Do NASCIMENTo mostrou os seguintes resultados:

Resíduo

Dureza total em $\mathrm{CaCO} 3$

Dureza cálcica

Acidez em $\mathrm{CaCO} 3$

$\mathrm{pH}$

Cálcio em Ca

Magnésio em $\mathrm{Mg}$

Cloreto em $\mathrm{Cl}$

Nitratos em $\mathrm{N}$

Nitritos em $\mathbf{N}$

Fosfato em PO4

Matéria orgânica em oxigênio consumido em meio ácido
$2,11 \mathrm{mg} .1$.

$470,11 \mathrm{mg} .1$.

$260 \quad \mathrm{mg} .1$.

$18,0 \mathrm{mg} .1$.

7,7

$104,0 \mathrm{mg} .1$.

$50,4 \quad \mathrm{mg} .1$.

$894 \mathrm{mg} .1$.

$0,008 \mathrm{mg} .1$.

$0,001 \mathrm{mg} .1$.

$0,36 \mathrm{mg} .1$.

$4 \quad \mathrm{mg} . \mathrm{l}$. 
Nesta data a cisterna tinha águas transparentes, com os ramos de Anacharis muito abundantes, mas quasi sem Lemna, tendo entre as fendas das pedras 3 ou 4 rãs Hyla que se nutriam a expensas dos produtos da cisterna. Havia alguns peixinhos Lebistes reticulatus que se alimentavam principalmente de Ostracoda e Copepoda. A água era de $\mathrm{pH}=7,1$;

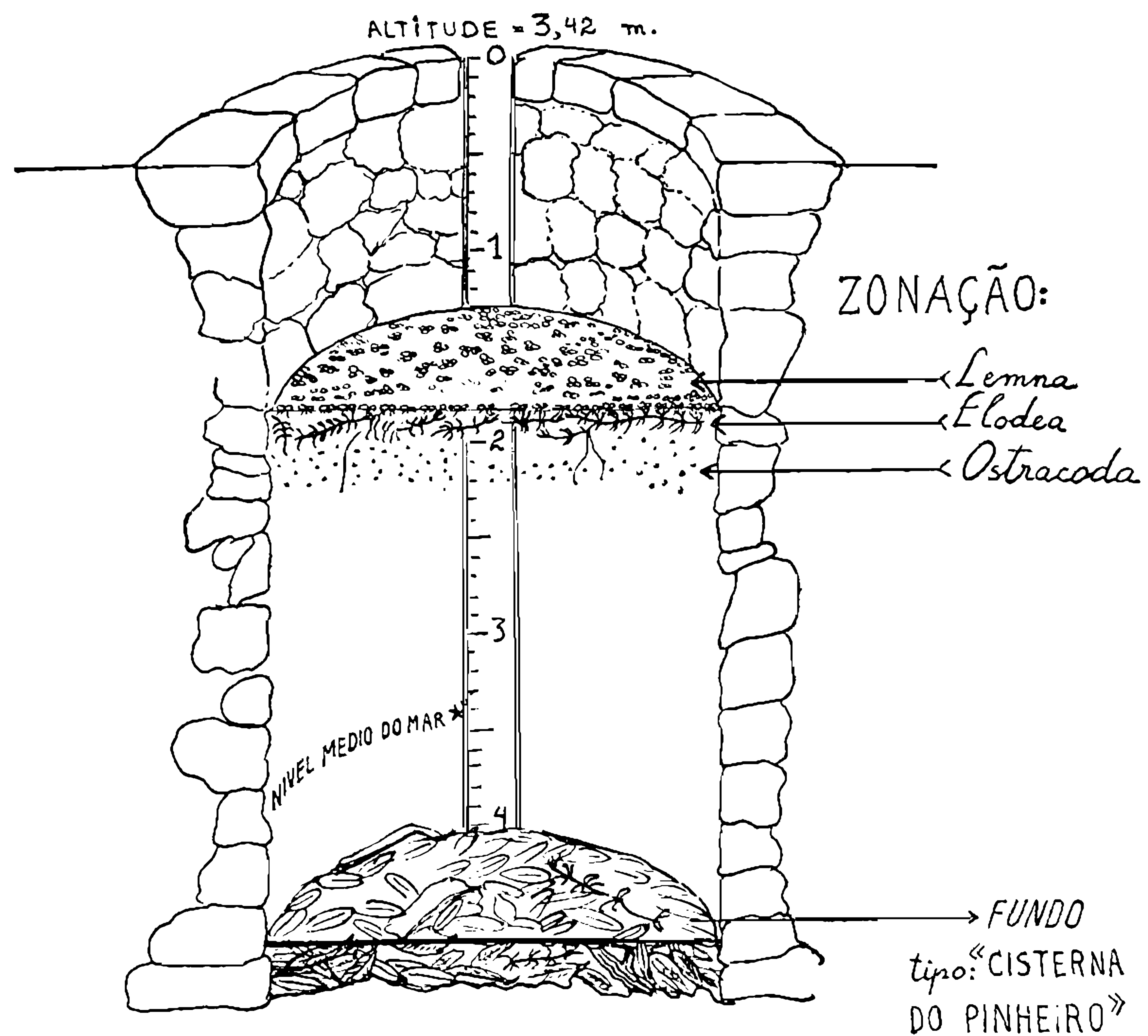

Figura 3 - Um corte do poço. A escala representa a régua para anotar as cotas limnográficas, está graduada de 0 a 4 metros. Vê-se o tapete de Lemna, pouco abaixo as Elodea e entre esta última e pouco mais para o fundo a população de crustáceos Ostracoda do gênero Spirocypris.

os cloretos estavam a $894 \mathrm{mg} .1$. , teor que já representa uma infiltração de $4,7 \%$ de água do mar, tornando-a medíocremente potável; os nitratos e fosfatos estavam, como se vê, em dose de adubagem. Somos obrigados a pensar que êstes fosfatos deveriam provir da decomposição de fôlhas mortas e da carne e de ossos de todos os animais que lá viviam e depois morriam lá deixando seus cadáveres. Conquanto o resíduo fôsse muito alto, aliás favorável á produtividade, esta não é grande nesta cisterna; uma das causas é a pequena iluminação recebida. Acrescentemos que de vez em quando caía um pequeno animal dentro da cisterna: entre êles um outro urubú, segundo foi visto pelas penas e pelo esqueleto quando fizeram a limpeza em 1938, e também várias vêzes por nós nas nossas dragagens. Os urubús vêm comer carniça no lixo do Cajú aqui ao sul e em frente á ilha do Pinheiro, e depois para êles irem á Santa-Cruz pousavam na Ilha do Fundão (mas esta ilha pas- 
sou para a cidade Universitária e os pousos foram acabados) agora êles pousam nas árvores da Ilha do Pinheiro. Em dezembro de 1951 caiu um porquinho de 7 kilos lá dentro, lá morreu, e foi retirado no dia seguinte. Depois desta ocasião o poço foi gradeado e nunca mais nenhum animal caiu. Em junho de 1952 houve dois casos de malária aqui na ilha, e desde esta ocasião houve intensa dedetisação para combate aos mosquitos, isto é o que causou não haver nenhuma referência a insetos nas águas desta cisterna, pois que êles não existem.

\section{DADOS LIMNOGRÁFICOS}

NIVEL DAS AGUAS - Tomando como ZERO a soleira da cisterna, teremos 4 metros para a profundidade máxima, quando estiver sêca. Estas cotas se lêm na régua limnográfica. Os níveis variaram pouco em 1952:

TABELA

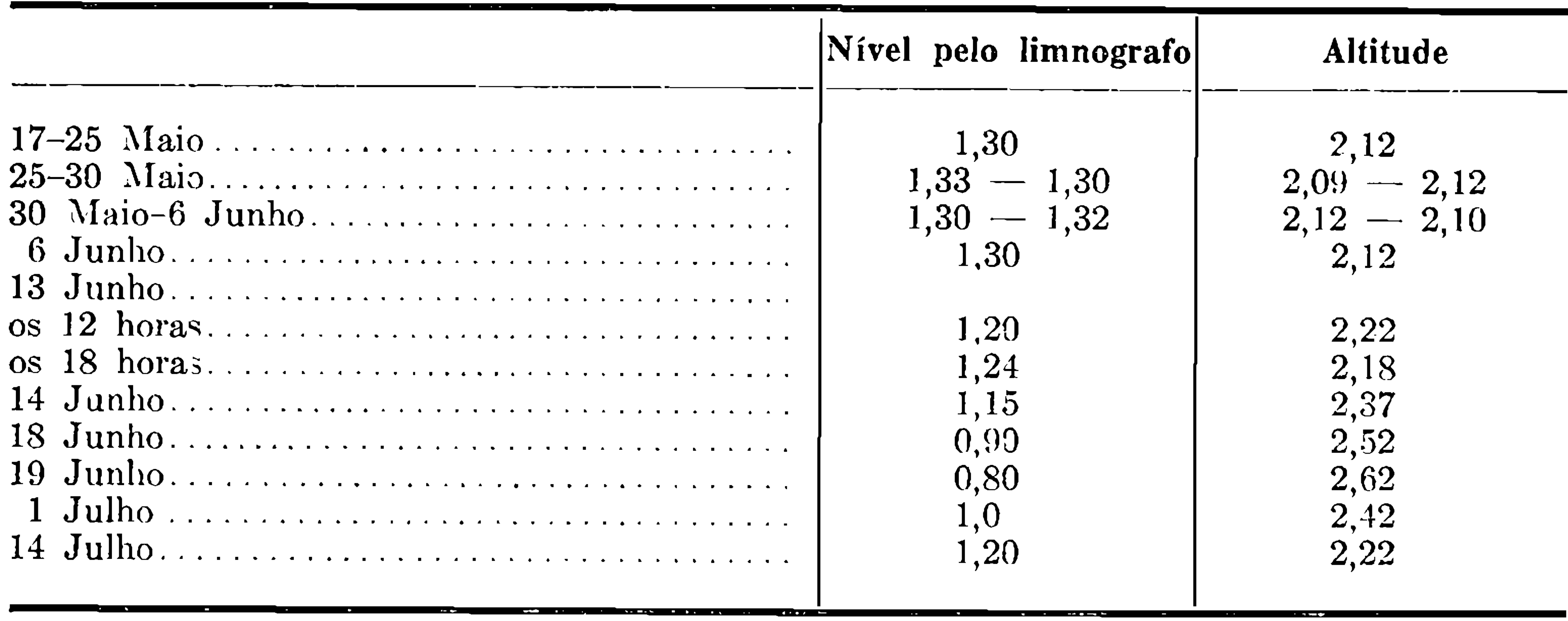

Cumpre notar que no nível das águas da cisterna há sempre variação diurna acompanhando simultâneamente o ritmo das marés, e nós pudemos perceber muito bem nos dias sêcos de maio de 1952, quando observamos detalhadamente êste assunto. Em 23 de maio ás 8 horas e 30 minutos, na Praia dos Macacos, a maré estava a $0,00 \mathrm{~m}$. do nível médio, quasi tão baixa como em certas marés de julho e de agôsto, e esta maré se elevou para $1,20 \mathrm{~m}$. ás 14 horas e 20 minutos, no dia seguinte estava a $0,0 \mathrm{~m}$. N.M. ás 9 horas $\mathrm{e}$ 15 minutos depois se elevando até $1,20 \mathrm{~m}$. ás 15 horas. O nível da cisterna sòmente variou de 1,33-1,41 m. limnográficos, fazendo uma amplitude total de 7 centímetros; êste fenômeno nos mostra que embora muito pequena há sempre uma certa influência marítima, as águas da maré comprimem as águas doces do lençol subterrâneo, cujo efeito aparece no nível da cisterna. Estas observações foram conduzidas devido a falta de chuva em maio, pois estas sempre alteram os níveis das águas.

Depois de 17 de maio, a primeira chuva ocorreu a 6 de junho, durando desde 8 horas da manhã até ao meio-dia, foi muito forte, pois 
caiu na zona da cisterna 39 litros de água por metro quadrado, o que corresponde a ter caído dentro da cisterna 130 litros (sua superfície exposta é de $\left.3,34 \mathrm{~m}^{2} ; 39 \times 3,34=130,2\right)$. Ora, a cisterna na cota em que estava tinha 9.103 litros de água, a queda de chuva veio diluir a salinidade (expressa em clorinidade de $\mathrm{C} 1=2,32$ por mil, para 2,30 e afetou sòmente a segunda casa decimal; expliquemos mais detalhadamente: na cisterna que estava com 9.103 litros com 23,2 kilos de $\mathrm{Cl}$, após as chuvas êstes se acharam em 9.233 litros. A mudança foi tão pequena que a cisterna não subiu nem mesmo 1 centímetro no seu nível limnográfico, mantendo-se em $1,33 \mathrm{~m}$. Porém 24 horas após, em 7 de junho, é que o nível da cisterna subiu: passou de 1,33 para 1,30 m. limnográficos, e a clorinidade caiu para 2,1. Ora se a cisterna subiu de 1,33 para 1,30 - ela subiu de 3 centímetros, o que corresponde a 100,2 litros, pois cada centímetro que sobe a água da cisterna são 33,4 litros; êstes 100 litros não dariam para baixar a clorinidade até 2,1 como foi verificado. Apreciação incontestável é que seja o efeito de diluição por capilaridade por permeabilidade da terra, é que fêz com que o teor de cloretos caisse a 2,1 por mil. Esste corresponde a um efeito de diluição de 943 litros, e não de 100 litros apenas. Então houve após estas primeiras chuvas os seguintes efeitos: 130 litros influenciaram a composição química das águas, por ser chuva caída diretamente dentro da cisterna, e mais 843 litros por trocas com águas telúricas difundidas e misturadas por capilaridade, sendo 130 litros "limnográficos" os que fizeram o nível da mesma subir 3 centímetros.

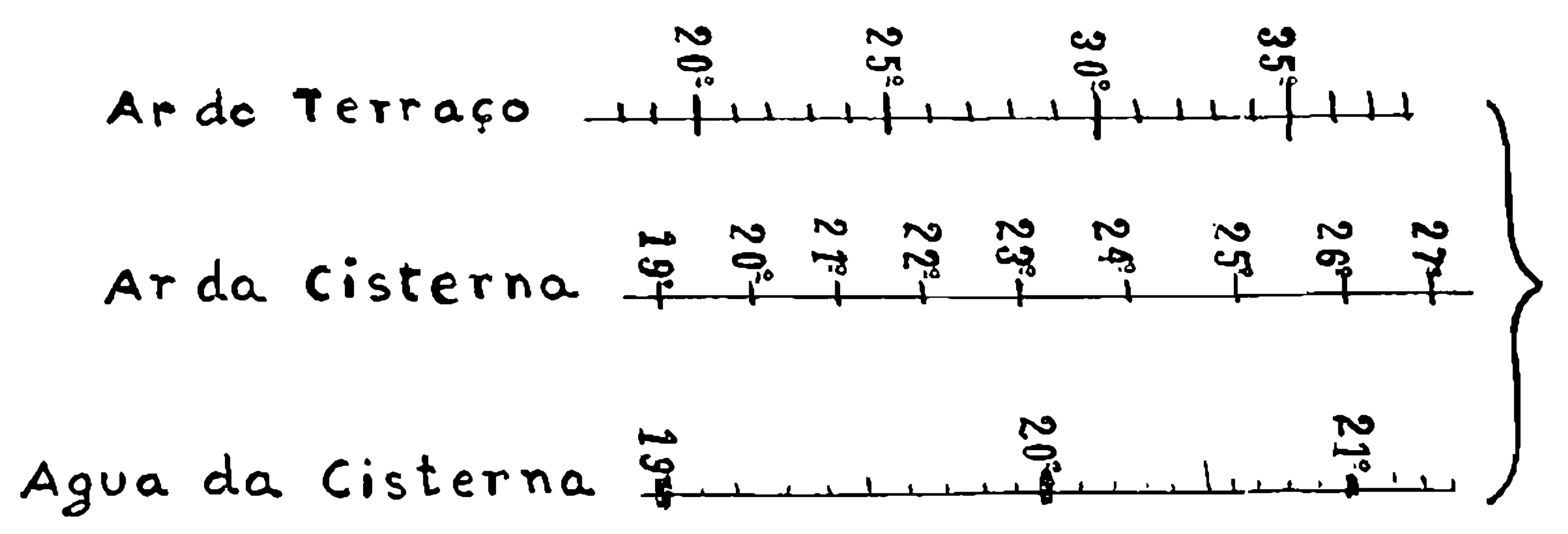

Fig. 4

TEMPERATURA - A temperatura das águas da cisterna é quasi constante, como se fôsse um aquário regulado para $19-20^{\circ} \mathrm{C}$. $\mathrm{Em}$ Maio de 1952 a temperatura oscilou de $19^{\circ}$ para $21^{\circ}$. Se compararmos com as temperaturas do ar no Terraço da Ilha (fig. 2) onde o sol bate diretamente não, havendo sombra a nenhuma hora do dia, veremos que houve neste dia uma variação de $20^{\prime \prime}$ até $38^{\prime \prime} \mathrm{C}$., mas no ar junto da cisterna houve uma variação menor, oscilando sòmente de $19^{\circ}$ até $27^{\circ}$, porque o ambiente é protegido por árvores e pelo Morro do Pinheiro. Junto da cisterna há humidade do ar, principalmente á noite: de 18 horas até 6 horas da manhã encontramos $87 \%$ até $91 \%$ de humidade. Ás 10 horas do dia esta caía para $30 \%$ no Terraço da Ilha, o que não acontecia, nem acontece nunca junto á cisterna aonde a humidade se mantém sempre, mesmo ao meio-dia. Durante o mês de Maio houve uma oscilação de $2^{\prime \prime} \mathrm{C}$. nas águas da cisterna entre a máxima e a mí- 
nima $19^{\circ}$ e $21^{\circ}$. Depois de observados os traçados de temperaturas feitos pelos termógrafos, estabelecemos uma relação entre os três climas: clima do Terraço da Ilha, clima do ar junto á cisterna, clima da água da cisterna, que foi a seguinte:

Enquanto a temperatura do ar no Terraço da Ilha sobe de $8^{\circ}$ a temperatura do ar da cisterna sobe apenas de $4^{\circ} \mathrm{C}$ e as águas da mesma cisterna sobem de $1^{\circ} \mathrm{C}$.; em regra geral ás águas mantinham até meio dia a temperatura mínima ocorrida durante a noite. Estas interrelações apresentamos nos gráficos da figura 4.

A seguir damos alguns dados obtidos representados em máximas e mínimas diárias expressas em graus centígrados.

TABELA

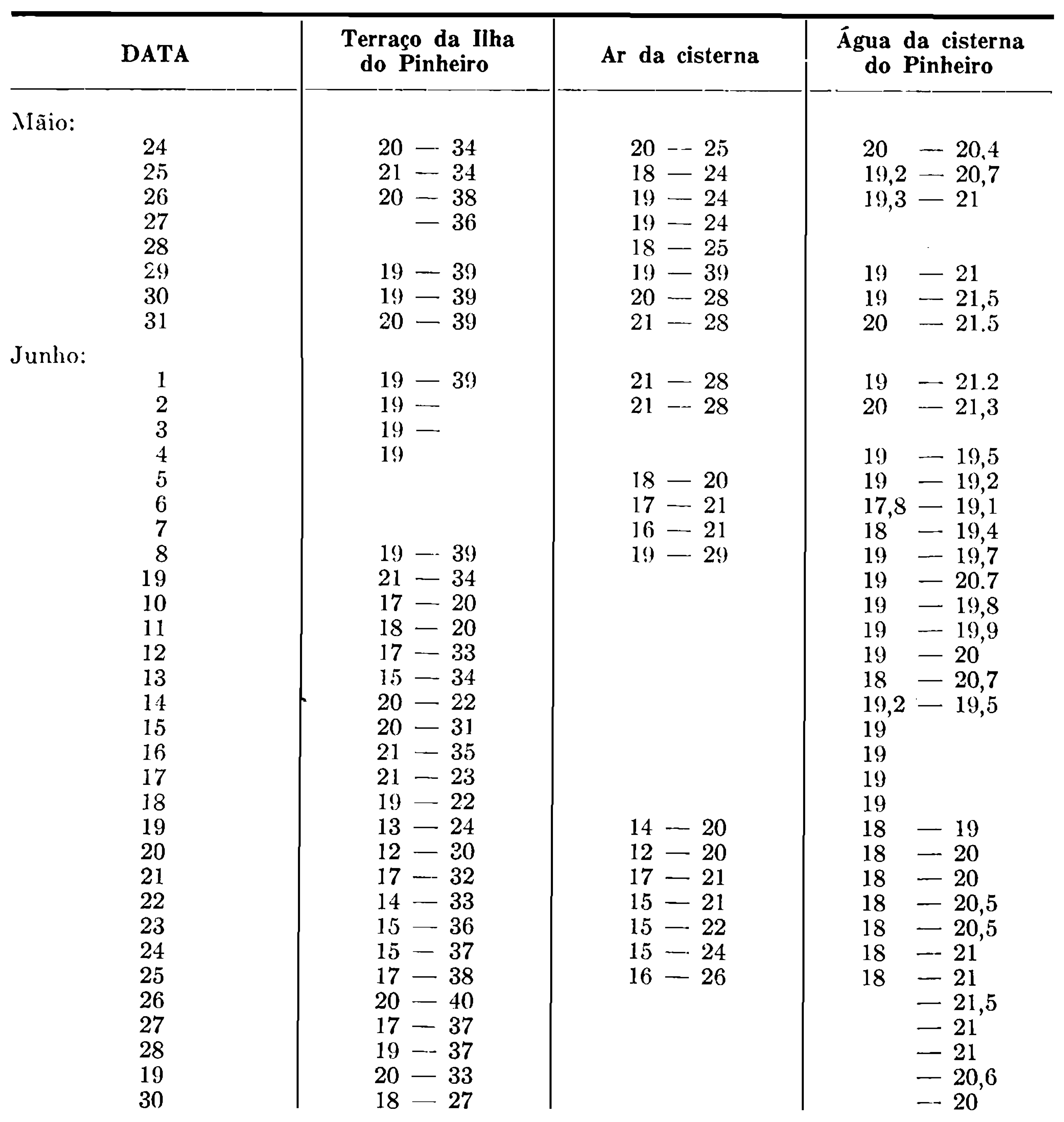




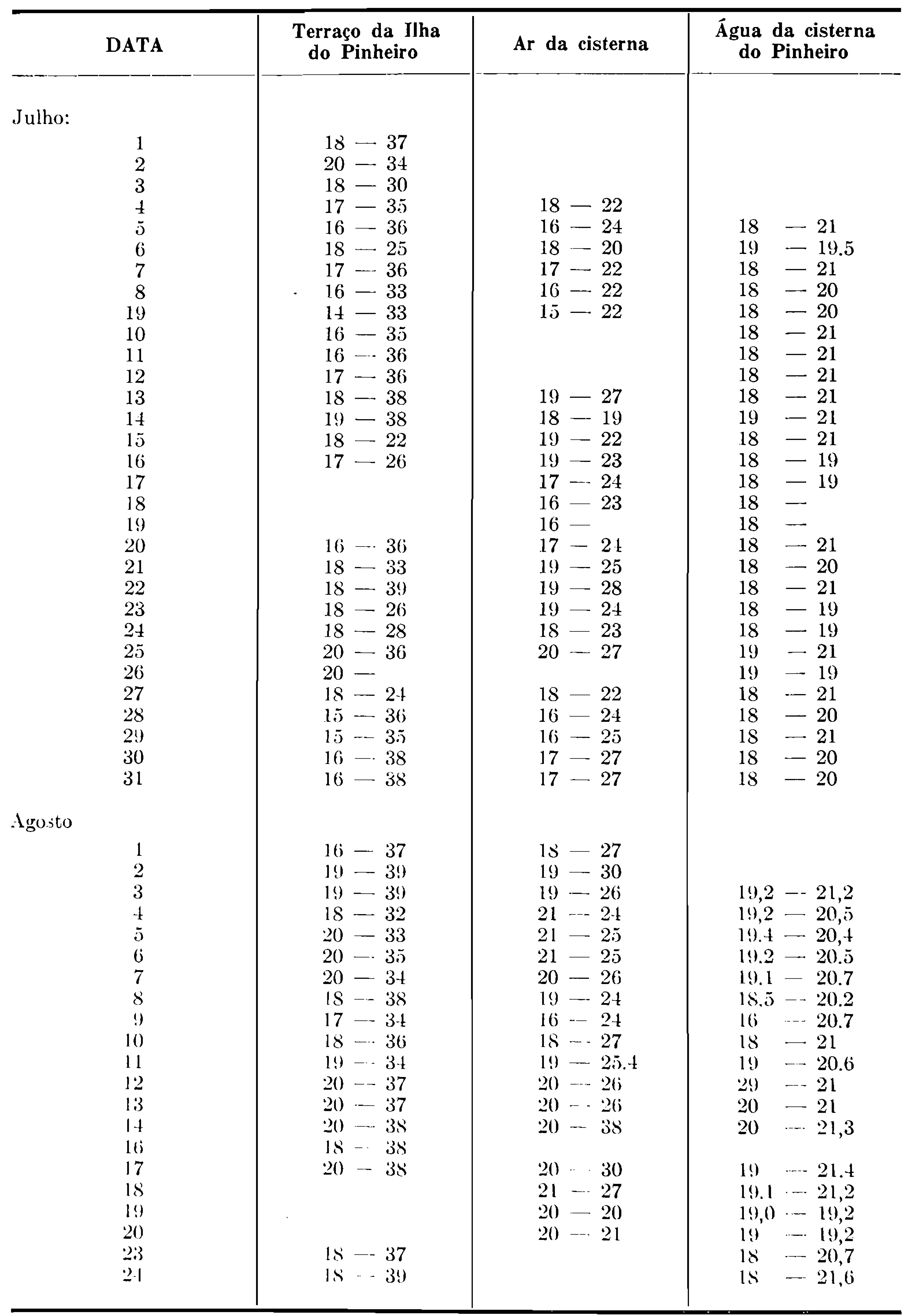


INSOLAÇÃO - poderemos observando pela posição da cisterna (como no esboço da fig. 2) com facilidade compreender que a insolação só é significativa e direta de 10 horas até ás 14 horas em Maio, quando o nível das águas está em 1,30 m. limnográficos. Quando a cisterna esteve vazia em 1938 o sol só caía no fundo de 10 horas e meia até 13 horas.

TERMOREGULAÇÃO - O lençol de água doce que alimenta a cisterna passa por baixo da Enseada de Inhauma, esta serve de enorme termoregulador. Para quem conhece o clima do Rio de Janeiro não é extranho observar dias em que a temperatura cai muito, principalmente no inverno, em Junho, em que chega a $15^{\circ} \mathrm{C}$ e mesmo a $14^{\circ}$, mas esta temperatura do ar é muito passageira geralmente ocorre sòmente durante a madrugada, já ao levantar do sol o termômetro sobe muito e continua subindo até cêrca de meio-dia, de modo que no maior tempo de sua existência, ás águas da cisterna ficam mesmo entre $19^{\circ}$ e $21^{\circ} \mathrm{C}$.

\section{CôR DAS ÁGUAS}

Foi tomada a côr aparente das águas, olhando-se para a cisterna, com uma placa de porcelana por baixo para tirar o efeito castanho escuro do fundo; e a côr chamada - côr verdadeira, pelo standard Methods for Water Analisis, também foi verificada no laboratório.

Um dos principais fundamentos das observações limnológicas é a côr aparente das águas. Nesta cisterna varia dentro do grupo de "verde bistre C.U.C. n. ${ }^{\circ}$ 261, 262, 263, 264" até ao "Ultramar amarelo C.U.C. 265". Em certas ocasiões a côr muda totalmente de tonalidade, transformando-se gradualmente, passando ao grupo dos verde maçã, mas muito claros, isto é, até "C.U.C. 270". Uma terceira tonalidade, resultante do progressivo metabolismo que surge em outras ocasiões, é a do grupo "Verde Lymphaceus" ficando as águas "C.U.C. 305", ás vêzes mais carregado as vêzes mais diluído.

TRANSPARÊNCIA - Com efeito, nunca a água é totalmente transparente - nunca se vê o fundo da cisterna, e nem mesmo um prato branco colocado no fundo. A transparência para o disco de Sechi é mínima de $0,60 \mathrm{~m}$. e máxima de $2 \mathrm{~m}$., necessàriamente tomadas em dias claros ao meio-dia. Esta falta de transparência corre por conta do plancton e de partículas grosseiras de detritos em suspensão, pois as águas em laboratório não apresentam turvação, tais foram os resultados das análises: Turvação em p.pm. de Sílica $=0,0$, em todas amostras analisadas.

A côr aparente da água na cisterna difere da côr verdadeira da água filtrada em laboratório, que variou entre 10 e $15 \mathrm{mg} .1$. em Platina.

Isto vem mostrar que o que dá a côr aparente é o plancton que varia, que dá por intermedio da côr de sua clorofila o aspecto Verde bistre, verde maçã, verde linfaceo, etc. 


\section{CHUVAS} foram:

Durante o período em que estudamos estas águas as precipitações desde 15 de Maio de 1952 até 5 de Junho: nenhuma chuva.

Os dias chuvosos foram:

JUNHO 1952

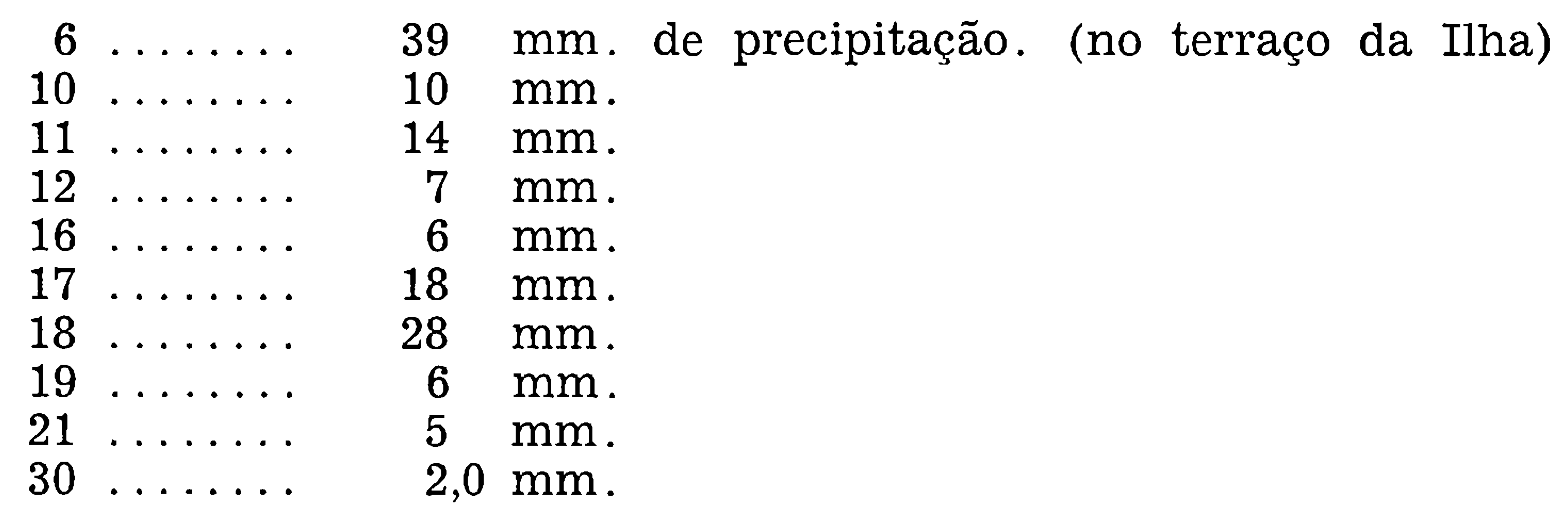

JULHO

$\begin{array}{rlcc}2 & \ldots \ldots \ldots & 1 & \mathrm{~mm} . \\ 3 & \ldots \ldots \ldots & 2 & \mathrm{~mm} . \\ 6 & \ldots \ldots \ldots & 6 & \mathrm{~mm} . \\ 8 & \ldots \ldots \ldots & 0,3 & \mathrm{~mm} . \\ 26 & \ldots \ldots \ldots & 13 & \mathrm{~mm} . \\ 27 & \ldots \ldots & 6 & \mathrm{~mm} .\end{array}$

AGÔSTO

$\begin{array}{rlrrr}8 & \ldots & \ldots & 7 & \mathrm{~mm} . \\ 19 & \ldots & 30 & \mathrm{~mm} . \\ 20 & \ldots & \ldots & 20 & \mathrm{~mm} .\end{array}$

SETEMBRO

$\begin{array}{rlrl}5 & \ldots \ldots \ldots & 2 & \mathrm{~mm} . \\ 6 & \ldots \ldots \ldots & 8 & \mathrm{~mm} . \\ 7 & \ldots \ldots & 2 & \mathrm{~mm} . \\ 9 & \ldots \ldots & 29 & \mathrm{~mm} . \\ 14 & \ldots \ldots & 24 & \mathrm{~mm} . \\ 18 & \ldots \ldots & 21 & \mathrm{~mm} . \\ 19 & \ldots \ldots & 5 & \mathrm{~mm} . \\ 20 & \ldots \ldots \ldots & 20 & \mathrm{~mm} .\end{array}$

\section{OUTUBRO}

$10 \ldots \ldots .3 \mathrm{~mm}$.

(de 12 de Outubro até 4 de Novembro: $63 \mathrm{~mm}$; em 9 de Novembro: $6 \mathrm{~mm}$. quando observações foram encerradas). 


\section{HIDROQUIMICA}

Resultados das análises executadas pelo Sr. Arnaldo Miranda, da Estação de Hidrobiologia, sob a orientação do Dr. Rubem NASCimento da Divisão de Química do Instituto Oswaldo Cruz.

Água da cisterna em longo período de sêcas, antes das chuvas, em 23 de Maio de 1952:

Côr mg.l. em platina $\ldots \ldots \ldots \ldots \ldots \ldots \ldots \ldots$ 10,0

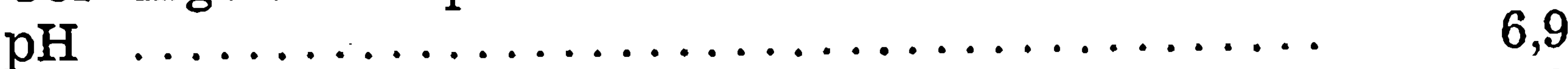

Substâncias sólidas dissolvidas g./l. ....... 5,243

Resíduo fixo total $\mathrm{g} . / 1 . \ldots \ldots \ldots \ldots \ldots \ldots \ldots \ldots$. 1,046

Cloretos gramas por litro ................. 2,414

Cálcio mg.l. ..................... 320,0

Magnésio em mg.l. ................. 240,0

Fosfatos (Orto), mg.l. ..............

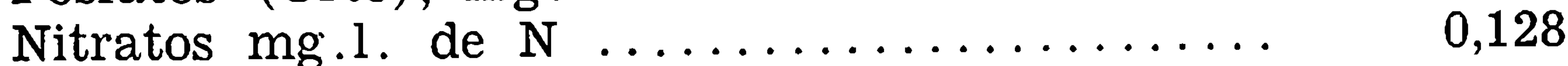

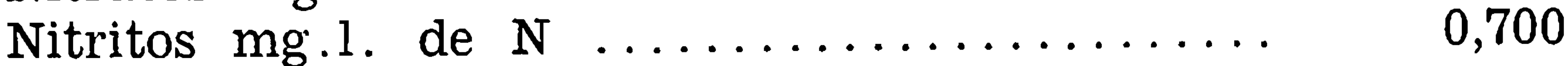

Oxigênio consumido em meio alcalino, mg.l. .. 1,0

Alcalinidade a fenoftaleína equiv. $\mathrm{CaCO} 3 \mathrm{mg} .1$. 13,0

Alcalinidade ao Indicador Mixto, equivalente a

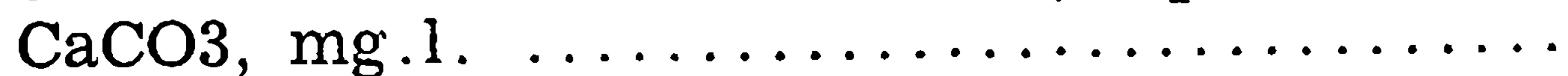

Amônia, mg.1.

318,0

0,08

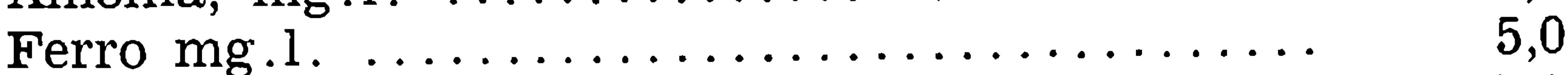

Sulfatos, mg.1. ................... 87,954

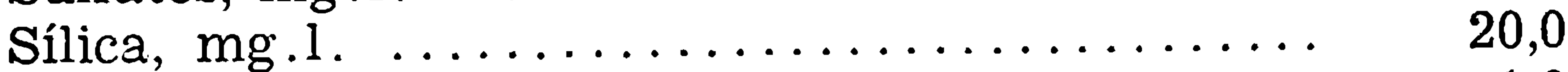

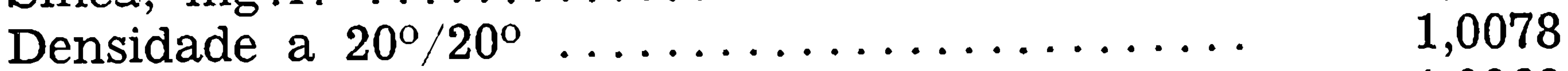

Densidade a $20^{\circ} / 4^{\circ} \ldots \ldots \ldots \ldots \ldots \ldots \ldots \ldots \ldots . \ldots \ldots$

Acidez total equivalente a $\mathrm{CaCO} 3 \mathrm{mg} .1 . \ldots \ldots$. . . 0

Turvação p.p.m. em Sílica ............ 0,0

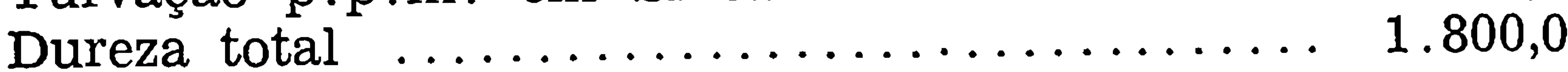

Dureza cálcica ...................... 800,0

Dureza magnésica .................. 1.000,0

Água da cisterna após as chuvas desde 6 de Junho, na cota 0,80 da régua limnográfica caindo um total de precipitação de $124 \mathrm{~mm}$. Amostra colhida em 19 de Junho de 1952.

Côr mg.1. em platina

Substâncias sólidas dissolvidas, g.l.

Resíduo fixo total g./l. ............... 1,889

Cloretos g./1.

1,775

Cálcio mg.l.

Magnésio mg.1.

192,0

Fosfatos (Orto) mg.l.

0,30

Nitratos mg.1. de $\mathrm{N}$ 
Nitritos mg.l. de $\mathrm{N} \ldots \ldots \ldots \ldots \ldots \ldots \ldots \ldots$. 0,030

Oxigênio consumido em meio alcalina, mg.l. . . $\quad 5,2$

Alcalinidade a fenolfaleína equiv. CaCO3 mg.l. 15,0

Alcalinidade ao Indicador Mixto, equivalente a

$\mathrm{CaCO} 3 \mathrm{mg} .1 . \ldots \ldots \ldots \ldots \ldots \ldots \ldots \ldots \ldots$

Amônia $\mathrm{mg} .1 . \ldots \ldots \ldots \ldots \ldots \ldots \ldots \ldots \ldots \ldots$

Ferro mg.1.

Sulfatos $\mathrm{mg} .1$

245,0

Sílica $\mathrm{mg} .1$.

Densidade a $20^{\circ} / 20^{\circ}$

5,0

156,346

22,0

Densidade a $20^{\circ} / 4^{\circ}$

Acidez total equivalente a $\mathrm{CaCO} 3$

1,0037

Turvação p.p.m. em sílica

0,0

0,0

Dureza total

$1.200,00$

Dureza cálcica

400,00

Dureza magnésica

800,00

\section{ANÁLISE}

9 de Agôsto de 1952; depois de uma dedetisação intensa na parede da cisterna, e no mato ao redor.

Côr mg.l. de platina

15

$\mathrm{pH}$

7,2

Substâncias sólidas dissolvidas g.l

4,785

Resíduo fixo total g.l.

1,815

Cloretos, em Clg.l.

2,206

Cálcio Ca, mg.l.

320,0

Magnésio mg.l.

240,0

Fosfato Orto, mg.l.

0,30

Nitratos $\mathrm{mg} .1$. de $\mathrm{N}$

0,100

Nitritos $\mathrm{mg} . \mathrm{l}$. de $\mathrm{N}$

0,004

4,0

0,0

Alcalinidade a fenolfateína em $\mathrm{CaCO} 3 \mathrm{mg} .1$. ...

Amônia mg.l.

1,1

Alcalinidade ao Indicador mixto, em $\mathrm{CaCO} 3 \mathrm{mg} .1$.

Ferro mg.l.

277,0

Sulfatos mg.1.

5,0

Sílica mg.l.

122,146

Densidade $20^{\prime \prime} / 20^{\prime \prime}$

22,0

Densidade $20^{\circ} / 4^{\prime \prime}$

1,0060

1,0042

0,916

Oxigênio dissolvido $\mathrm{mg} .1$.

12,0

Acidez total em $\mathrm{CaCO} 3 \mathrm{mg} .1$.

$1.800,0$

Dureza total

800,0

Dureza cálcica

$1.000,0$

Dureza magnésica 


\section{SISTEMÁTICA}

Lista da flora e fauna: guinte:

O material biológico relacionado com as águas da cisterna é o se-

$$
\text { F L O R A }
$$

DIVISÃO SCHIZOPHYTA

CLASSE SCHIZOMYCETES

Ordem BACTERIALES

Família Coccaceae

Streptococcus sp.

Sarcina sp.

Micrococcus sp.

Família Spirillaceae

Spirilum sp.

Ordem Thiobacteriales

CLASSE SCHIZOPHYCEAE

Família OSCILLATORIACEAE

Oscillatoria tenuis Ag.

Oscillatoria sp.

Phormidium sp.

DIVISÃO BACCILARIOPHYTAE

Ordem Pennales

NAVICULOIDEAE

Stauroneis anceps Ehrenberg.

Stauroneis anceps var. linearis Kuetzing.

Stauroneis salina W. Sm:

Genero Navicula Bory

Navicula sp.

Genero Cymbella Agardh

Cymbella sp.

Gomphonema brasiliensis Schmidt

Comphonema acuminatum Ehrenberg 
MONORAPHIDAE

Cocconeis forcipata Schmidt

Genero Fragillaria Lyngbe

Fragillaria sp.

NITZSCHIOIDEAE

Nitzschia vitrea Norman

RAPHIOIDEAE

Eunotia aequalis Schmidt

Raphoneis sp.

$A R A P H I D A E$

Synedra ulna (Nitzsch) Ehrenberg.

\section{DIVISÃO CHLOROPHYCEAE}

Ordem Ulotrichales

Ulotrix sp.

Ordem Siphonales

Genero Vaucheria De Candolle

Vaucheria sp.

HETEROCONTAE

Tribonema sp.

DIVISÃO EMBRIOPHYTA SIPHONOGAMA

Familia $H Y D R O C H A R I T A C E A E$

Anacharis canadensis (Mich.) Planch.

$=$ Elodea canadensis

Familia $L E M N A C E A E$

Lemna minor $\mathrm{L}$. 
PROTOZOA

\section{CILIOPHORA}

Ordem Holotrichida

familia Holophriidae

Genero Prorodron

Prorodron sp.

Familia Tracheliidae

Genero Amphileptus Ehrenberg

Amphileptus sp.

Familia Paramecidae

Genero Paramecium Hill

Paramecium sp.

Ordem Hypotrichida

Familia Oxytrichidae

Stylonichia pustulata Ehrenberg

Genero Pleurotricha Stein

Pleurotricha $\mathrm{sp}$.

Familia Euplotidae

Euplotes charon Mueller

Ordem Peritrichida

Familia Vorticellidae

Vorticella sp.

Phylum ROTATORIA

Ordem Notomatida

Genero Diglena Ehrenberg

Diglena sp.

Genero Monostyla Ehrenberg

Monostyla sp.

Familia Gastropodidae

genero Brachionus Ehrenberg 


\section{CLASSE CRUSTACEA}

Subclasse OSTRACODA

Spirocypris sp.

Subclasse COPEPODA

Eritrodiaptomus sp.

CLASSE INSECTA

Ordem DIPTERA

Anopheles tarsimaculatus, mosquito da malária Chironomus sp.

Phylum MOLLUSCA

Classe GASTROPODA

Lymnaea sp., molusco "grão de arroz".

Superclasse PISCES

Lebistes reticulatus, peixinho de aquário.

Classe $A M P H I B I A A$

Hyla sp., rã

Classe AVES

Ordem FALCONIFORMES

Coragypes atartus foetens, urubú.

Classe MAMMALIA

subordem SUIFORMES

Sus scrofa domesticus, porco.

O mosquito Anopheles tarsimaculatus não existe, nem nunca existiu nas águas da cisterna, mas em umas poças salobras muito próximas a esta cisterna, por isso é que houve a dedetisação, assim havendo seja como fôr, uma influência indireta.

\section{POSIÇÃO LIMNOLÓGICA}

Limnològicamente as cisternas se dividem em 2 grupos: naturais (as que provém de antigos lagos, as que transformar-se-ão em futuros lagos, as que ficam sempre cisternas e podem ter várias origens) e 
aquelas que são artificiais. Nas artificiais há umas que tem estagnação e desequilíbrio influenciado ou não pelas chuvas. A "Cisterna do Pinheiro" é do grupo das de amplitude influenciada pelas chuvas, assim como a composiçẫo química. Quanto a temperatura ela é do grupo das que são influenciadas pela temperatura do ar, com temperatura relativamente constante, devido a regulação de grande lençol de água subterrâneo que fica por baixo de uma grande massa de água do mar, cuja temperatura não cai abaixo de $18^{\circ} \mathrm{C}$. É do grupo das cisternas de água permanente, totalmente abertas, recebendo a iluminação do sol.

E uma cisterna do tipo das cavadas em litoral e em "floresta" de águas relativamente claras, com turvações periòdicas por épocas das chuvas. Não há nenhuma cisterna no clima sub-tropical descrita com todos os dados e informes necessàriamente e suficientemente técnicos, exigidos pelas ciências hidrobiológicas.

Há interêsse em se conhecer o grau de estabilidade do povoamento de uma água, e é mais fácil em uma massa pouco volumosa como a de uma cisterna. Neste problema os hidrobiologistas consideram dois aspectos: a persistência das mesmas espécies nas águas e a persistência das relações numéricas entre as espécies constituindo uma biocenose. São pois dois aspectos: a eclipse de uma espécie e o aparecimento de uma outra espécie, resultado o deslocamento da expressão numérica da estrutura da biocenose. Para constatação da aparição ou do desaparecimento de uma espécie há necessidade de controles minuciosos. Os números que traduzem a estrutura de uma biocenose, traduzem uma condição de equilíbrio entre os constituintes da sociedade e seu conjunto em relação ao meio. Por isto é que tais constatações numéricas tomam um certo fundamento. $\mathrm{E}$ mesmo notemos que pode romper-se o equilíbrio de uma biocenose, sem que haja mudança na parte qualitativa das espécies, sem que haja nenhuma alteração na "Lista da Flora e Fauna".

Veremos primeiramente as associações de carácter permanente.

ASSOCIAÇÕES PERMANENTES - Os sêres permanentes se dispõem na seguinte zonação flutuante: a cisterna apresenta a superfície de suas águas coberta por uma camada de plantinhas do gênero Lemna, cujas folhinhas muito verdes formam um tapete, quasi completamente fechado e impedindo em muito a penetração da luz (fig. 3). Esta planta oferece associações de caráter aéreo e epifítico: certos insetos e aracnideos que vivem por cima das folhinhas. Nas raízes das Lemna há uma associação que possìvelmente tenha exigências subaéreas, onde vivem as Vorticellidae, pois quando às Lemna são transportadas para o laboratório, para debaixo d'água, no aquário, imediatamente desaparecem as Vorticella e os Rotiferos; mas não é sòmente epifítica, pois que os Vorticellidae vivem neste nível sub-aéreo, fixos a suportes de pedaços de madeira, de galhos, de fôlhas sêcas flutuantes. Talvez êstes animais necessitem uma quota maior de oxigênio, que existe nas proximidades da película superficial. Também em caráter 

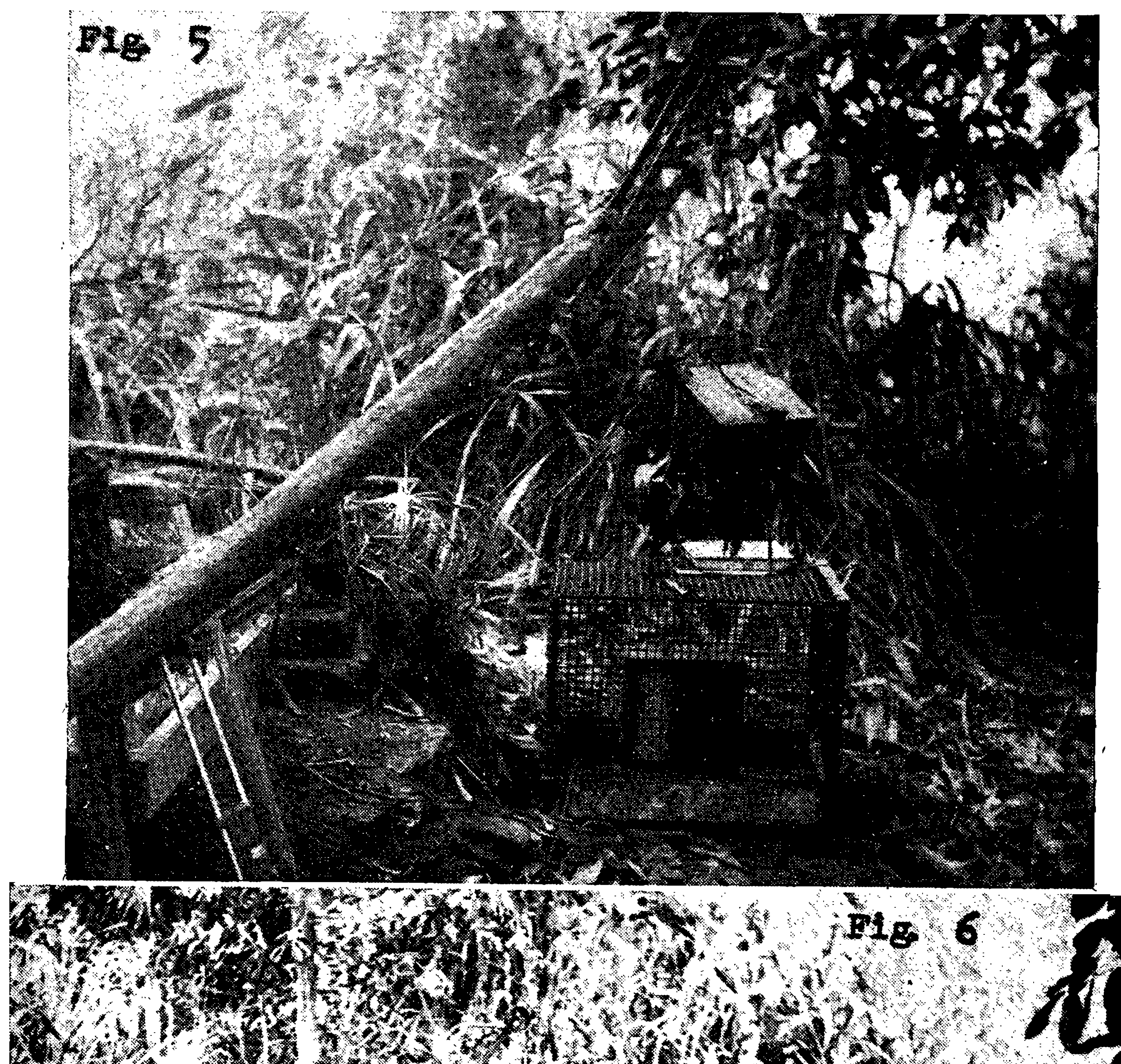

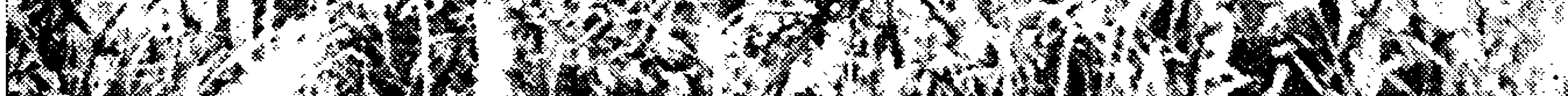

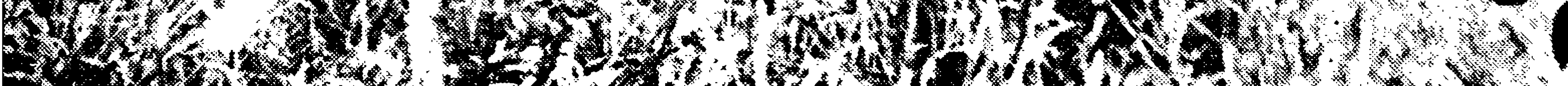

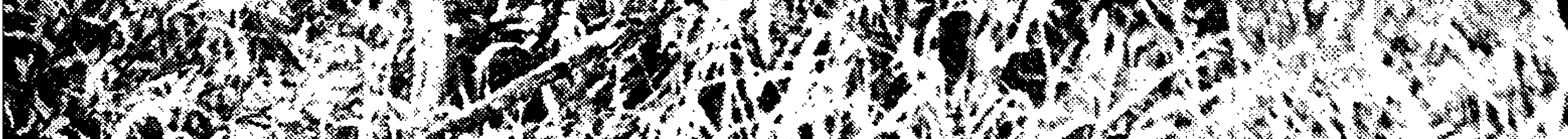

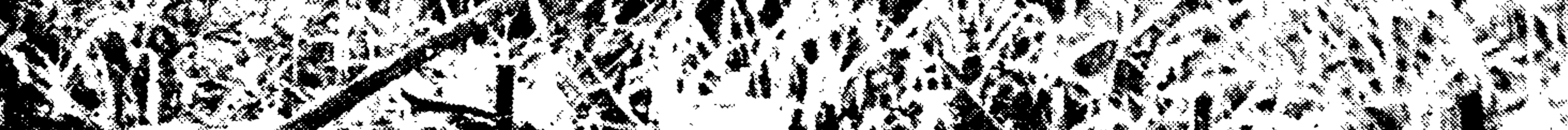

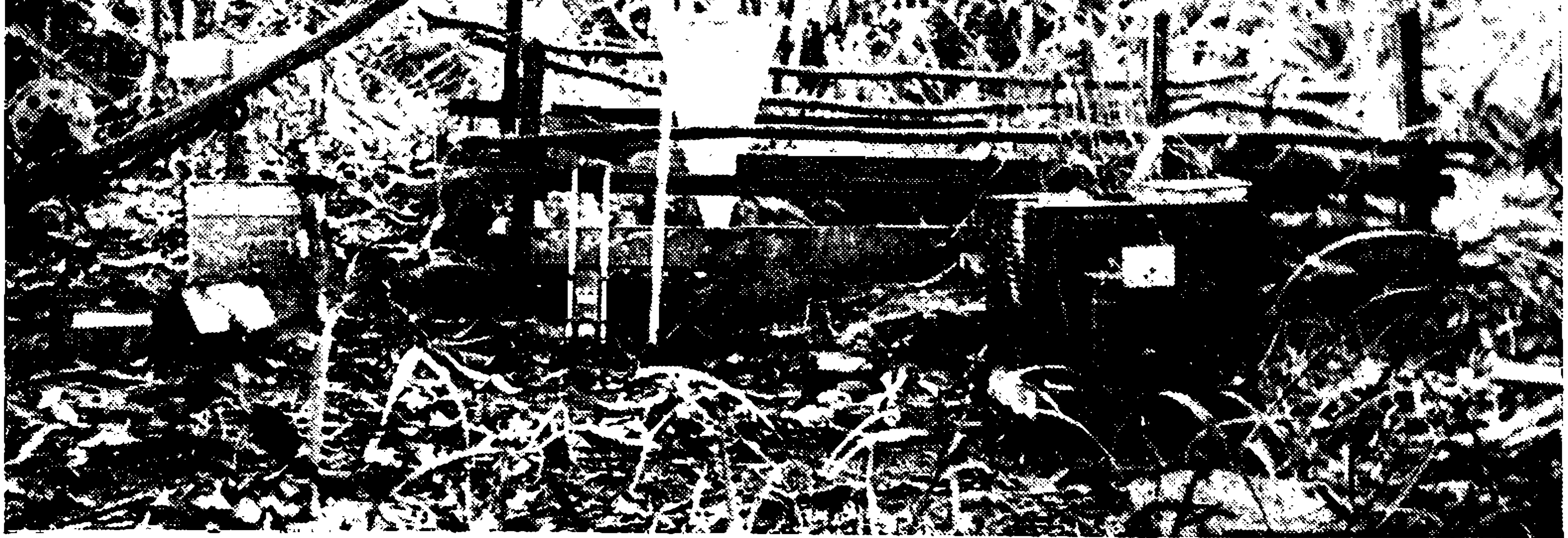

Figura 5 - Ao lado da cisterna do Pinheiro: A draga trazendo as fólhas pôdres do fundo, a gaiola em que está o registrador para temperatura, pressão e humidade do ar junto a cisterna. Ve-se o capim palha, e ramos de um pé de jamelão.

Figura 6 - A cisterna tem uma grade rústica, feita para os porcos e as preás não caírem dentro, está em pleno mato. 


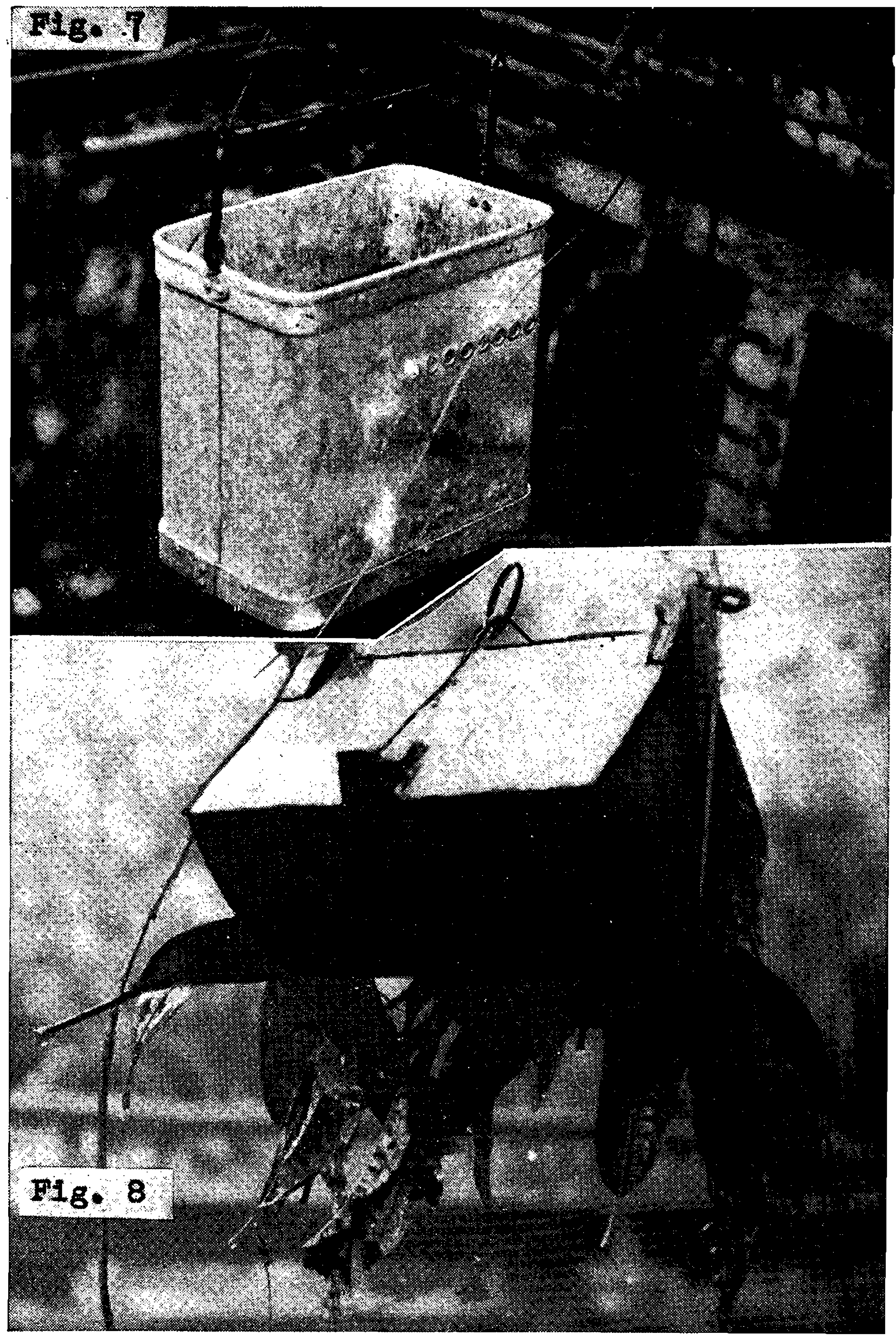

Figura 7 - O balde de Friedinger, para contagens, nos furos arredondados êle esvazia exatamente em 10 litros.

Figura 8 - A draga de Pertersen, fabricada por Hans FrIedinger, Luzern, trazendo uma amostra do fundo: fôlhas de jamelão e mangueira, detritos de vegetais, alguns tijolos se desfazendo. 
Mem. Inst. Oswaldo Cruz

Tomo 51, 1953

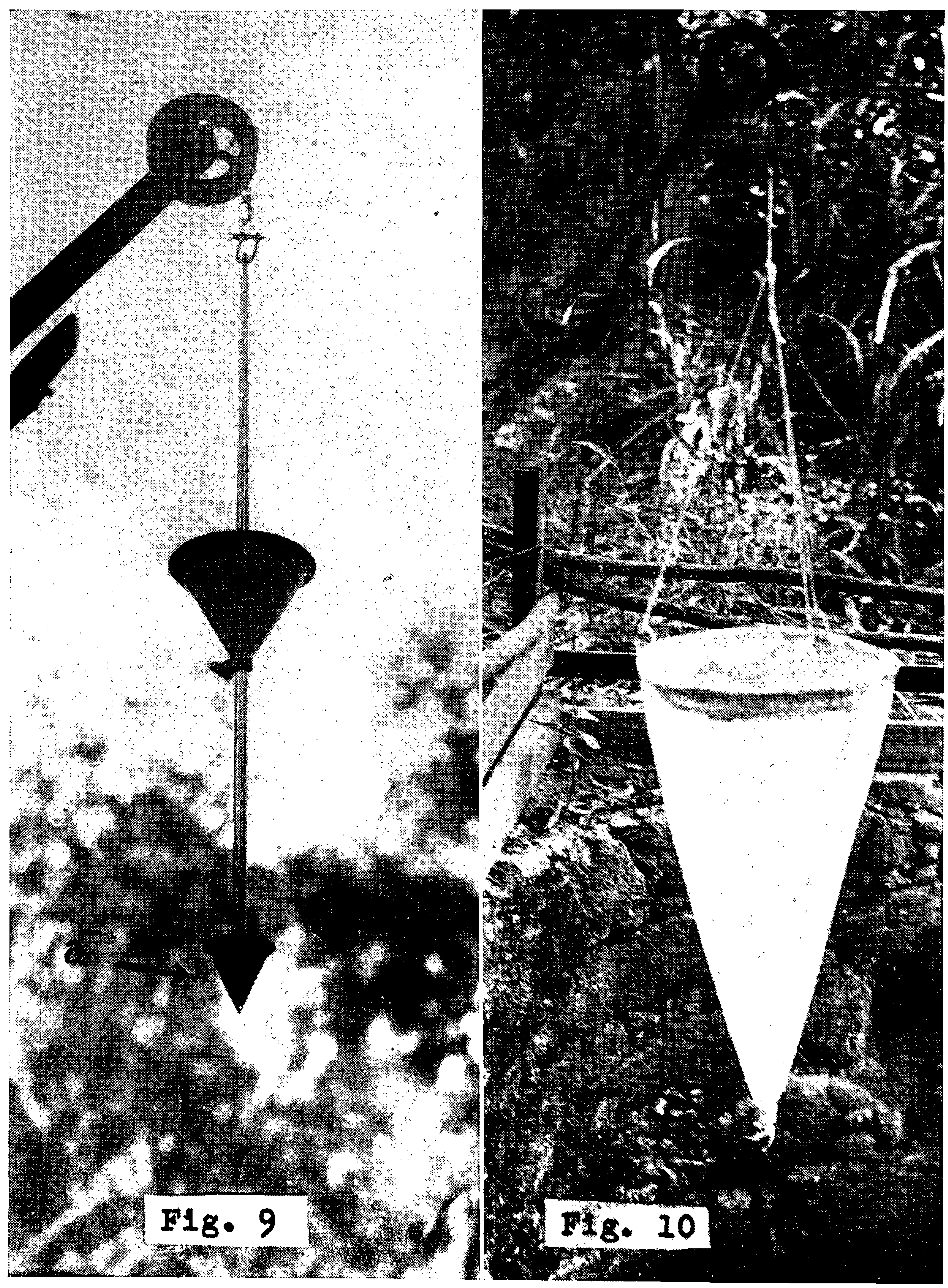

Figura 9 - o Sondador de Friedinger descendo: êle atravessa a camada de fôlhas e traz o material de argila preta do fundo. Em baixo: a "draga de copo"': (a).

Figura 10 - uma rêde de Plancton qualitativa, ao descer. 
Mem. Inst. Oswaldo Cruz

Tomo 51, 1953

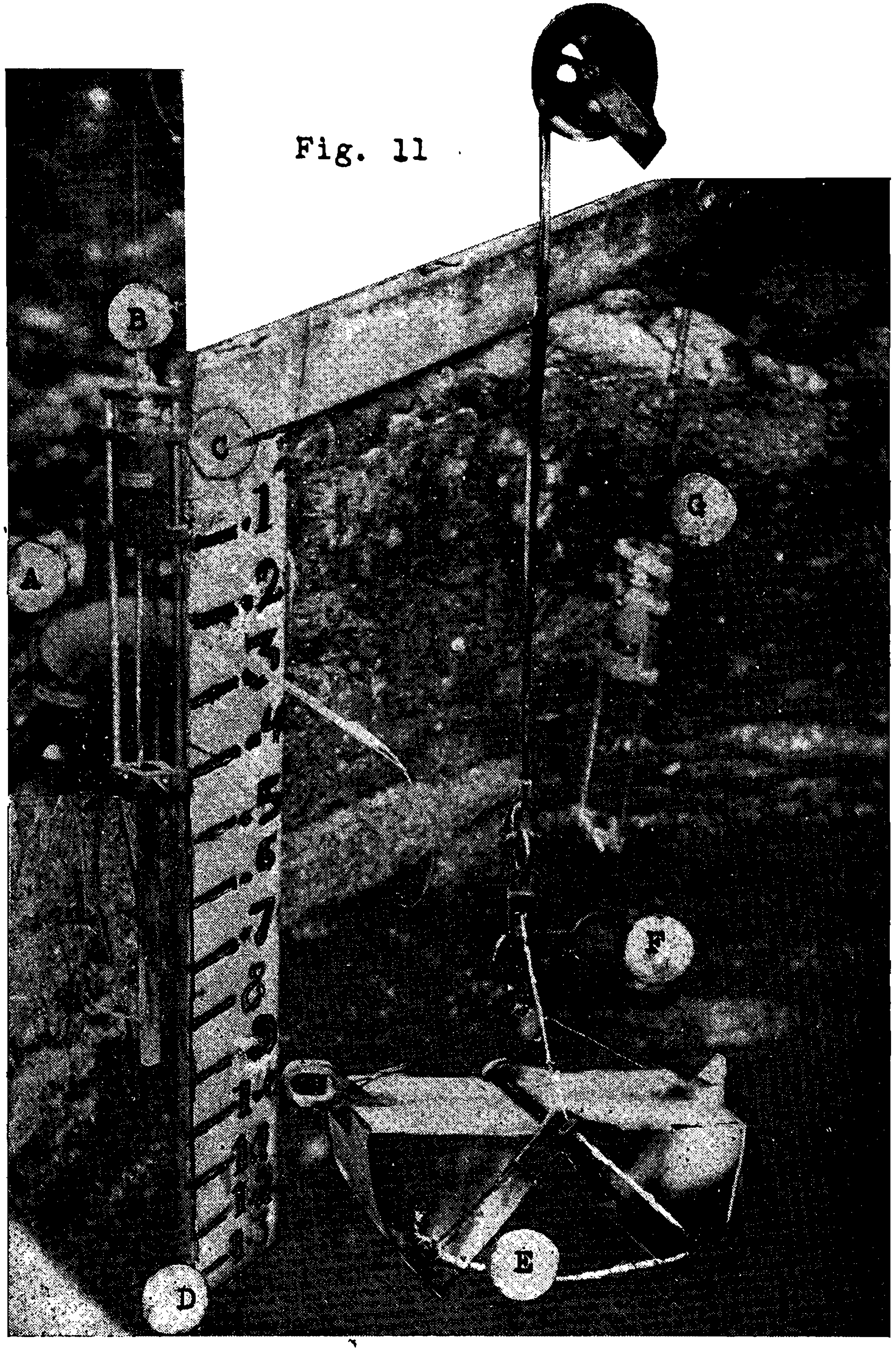

Figura 11 - A - uma peneira, do Tipo de "peneira de Allen" para estudo do fundo. B - sondador de fundo, da parte mais macia, de vidro, de Friedinger. C - a cota ZERO da soleira, ZERO limnográfico da cisterna D - vê-se que no momento em que foi tirada esta fotografia a água estava a $1,33 \mathrm{~m}$. Reparar que para contagem de altura d'água pelo nível o volume de água sobe quando a altura desce em relação a cota ZERO da soleira. E - a draga de Petersen aberta, com o seu disparador F. Em G: um sondador de vidro descendo. 
permanente existe um pouco mais para o fundo, num nível de 20 até 60 centímetros abaixo da película superficial, uma zona em que a espécie predominante é a elódea Anacharis canadensis. Estas elódeas dão um total de 8 litros, ou seja para facilitar, 250 plantinhas de $1 / 2$ metro de comprimento cada uma, estão em fase de equilíbrio, sua população está estabilizada, não há aumento nem diminuição do número de espécimes. Entre as elódeas é que habita o planctor mais rico, mas a relação numérica entre os vários planctontes. assim como a presença e ausência de alguns dêles, não tem caráter de permanência: ora predomina um copepodaplancton, ora um ostracodaplancton, havendo uma série de elementos, em menor número, como sejam: fitoflagelados, protozoários Thurícola, ciliados, coanoflagelados, rotífera. São muito comuns as vortícelas qua se desprendem do suporte e nadam livremente, há raros Actinophrys sol, muitas diatomáceas Naviculáceae em discos flutuantes de massas gelosiformes muitos Gastrotrichas e rotíferos Brachionus, Monostyla, alguns filamentos de heterocontas, de oscilatórias, de Phormidium entre detritos vegetais numerosíssimos.

O plancton é mais abundante na zona superior, não é sòmente a mais arejada, assim como a mais doce, pois que ás aguas do fundo são pouco mais salobras.

\section{ASSOCIAÇÃO EPILITICA PERMANENTE}

A ecologia dos grupamentos constitue necessàriamente uma base de classificação: entre outros há um grupamento na parede vertical da cisterna e outro no fundo. A parede da cisterna é de pedra e nela crecem vários sêres microscópicos principalmente as diatomáceas do gênero Gomphonema. Nestas paredes é que andam os moluscos "grãozinho de arroz" Lymnaea sp., comendo os sêres que aí crescem, limpando a parede. Estas Lymnaea também andam nos ramos das Elodea, é raro apanhar uma viva andando no fundo da cisterna. No laboratório as Lymnaea crescem mais abundantemente quando as águas tem $200 \mathrm{mg}$. 1. de nitrato de amônio (meio IV). No laboratório els.s andam no fundo do aquário.

Sempre que se pesquisa a parede da cisterna, sempre se encontra esta associação.

ASSOCIAÇÕES TEMPORÁRIAS: Primeira fase: Consideremos a cisterna no período de sêca, com águas de $\mathrm{pH}=6,7$ a 7,0 , côr no grupo verde linfáceo, que é o das águas pardas por substâncias húmicas, pela tinta castanha que sai das folhas em decomposição, com transparência de 1 metro pelo repouso prolongado. Impressionante era que a população platônica de copepodos vivia exuberantemente.

Havia 2,414 mg.1. de cloro, ou seja expresso em salinidade $\mathbf{S}=$ 3,5 por mil. O cálcio estava em politipo: 320; o mesmo acontecia com o magnésio: 240; sais que provinham de influência marítima, de dureza magnésica maior que a calcica. Os fosfatos estavam em mesotipo; os nitratos em oligo-tipo com $0,128 \mathrm{mg}$. 1. enquanto que os ni- 
tritos eram apenas apreciáveis. Oxigênio consumido em meio alcalino em oligotipo, o ferro e os sulfatos em politipo.

A vista destes dados, as águas da cisterna encontravam-se nesta fase em regime oligohalina, correspondente a $10 \%$ de água do mar em água doce, com sulfatos em politipo.

Se prescutássemos suficientemente esta questão, teríamos de ver com os elementos que existem na água do mar em pequenas doses co. mo os iodetos, molibdenio, zinco, cobre, manganez pois êstes tem grande influência (haja visto a "solução AZ" para cultivo de algas que leva iodetos, molibdenio, zinco, cobre, manganez, boro, alumínio, estroncio, níckel, cobalto, titânio, brometos, etc...) E muito diferente $10 \%$ de água do mar total, de apenas alguns sais marinhos em mesma proporção. Há de se reconhecer que os cloretos não são geralmente desnecessários e totalmente inúteis mesmo para a nutrição de certas algas de água doce, quanto mais nas cisternas litorâneas em que as espécies são oligohalobias.

A concordância entre os fenômenos físicos, químicos, com a predominância dos copepodos conduz-nos a conceber a existência desta "fase de copepodaplancton" que permaneceu até ao dia 20 de Maio de 1952 .

Desequilíbrio - Os limites entre a fase copepodaplancton e a fase de desequilíbrio são apreciáveis e bruscos. O nível das águas baixou até $1,41 \mathrm{~m}$. limnográficos, os sulfatos chegaram até $260 \mathrm{mg} .1$.; êste teor está demonstrado ser a intensidade ótima para o crescimento sobretudo de certas tiobactérias que produzem gaz sulfídrico por uso dos sulfatos. O teor de sulfatos caiu para $87 \mathrm{mg} .1$. em 23 de Maio, 5 dias após o início do desequilíbrio. Êstes fatos concorrem para ilustrar o porque destas águas de 18 a 20 de maio, passaram a não prestar ao desenvolvimento dos copépodos e começou a mortandade de plancton nesta ocasião. No fundo da cisterna o cheiro sulfidrico era intenso e observou-se o seguinte bentos: argila de côr preta misturada com detritos, quasi pretos, de decomposição de numerosos vegetais, muitas partículas de carvão, havia sòmente 3 ostracodos vivos, uma ou outra diatomáceas Fragillaria, Navicula, Gomphonema viva, e o resto do material bentônico todo morto: ostracoda, copepoda e Lymnaea. De 21 a 24 de Maio o cheiro sulfídrico já ía desaparecendo, e na amostra de fundo já havia em cada "dragagem de copo" os seguintes elementos vivos: Fragillaria - 4; Navícula - 2; Achnanthes - 1; ostracodos Spirocypris - 3; Todas as Lymnaea estavam mortas. Nesta ocasião predominava com muita vitalidade no bentos esquizofíceas Phormidium $\mathrm{sp}$. e Oscillatoria $\mathrm{sp}$. A côr aparente da água nesta fase era amarelo esverdeado "Lymphaceus côr n. ${ }^{\circ}$ C.U.C. 305", vista por cima do disco de porcelana de 1 pé de diâmetro. A transparência com êste disco era de 1 metro. Esta fase de desequilíbrio foi de 17 a 29 de Maio, já no fim da fase apareciam em cada 20 litros de plancton: 5 ostracodo, 1 Lymnea e 1 copepodo vivos. Já no fundo aparecem os protozoários retráteis Vaginícola sp. Notemos que também houve alterações físicas, pois o poço estava a $1,41 \mathrm{~m}$., desceu de 7 centímetros o seu nível. Re- 
sumindo: esta fase é a de um desequilíbrio por gaz sulfídrico em um regime oligohalino a $10^{\prime} \prime$ de água de mar, com sulfatos em politipo: mortandade de copepodos e de ostracodos.

OUTRA FASE: Os tracodaplancton - uma outra fase do ciclo hidrobiológico da cisterna do Pinheiro é a "fase de ostracodaplancton", que vem com dominância dos ostracodos do gênero $S p i$ rocypris (veja o diagrama da figura 12). Quando êstes ostracoda prevaleceram houve: 1.') uma grande chuva que alterou a côr das águas, estas passaram ao grupo" verde maçã" cujas cores de verde puro não apresentam vestígios de serem tingidas por húmus castanho. $2 .^{\circ}$ ) um aumento de salinidade após a primeira chuva. $3 .^{\circ}$ ) desaparecimento do gaz sulfídrico. 4.") clorinidade compreendida entre 2,5 e $2,0 \mathrm{~g}$. de cloro por mil. Quando a clorinidade caiu para 1,9 os ostracoda morreram em massa, e as águas mudaram de tonalidade restituindo os antigos "verdes linfáceos" tingidos pelos castanhos das fôlhas em decomposição .

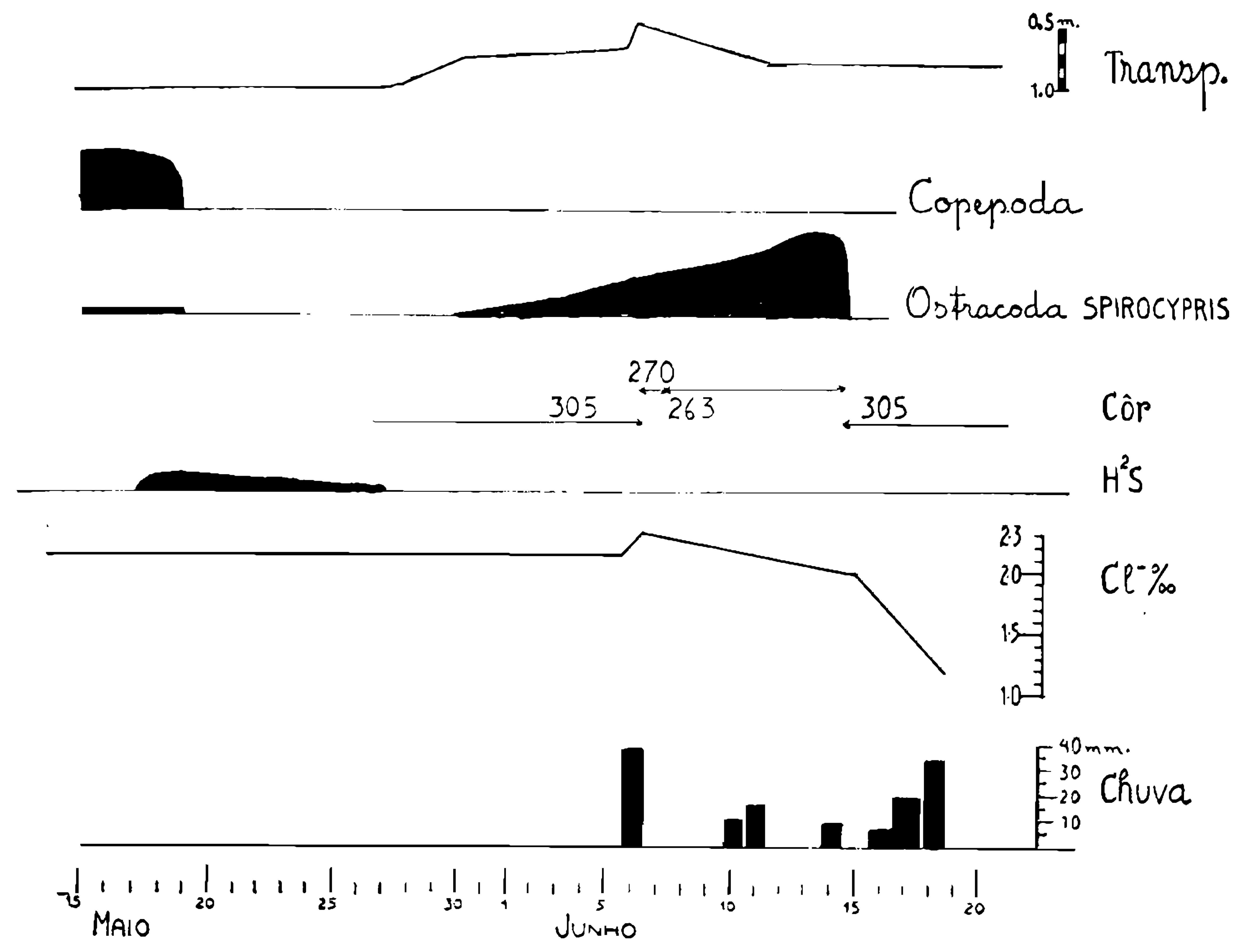

Figura 12 - Ciclo hidrobiológico.

Quando a coloração entrou no grupo "verde maçã" a transparência caiu muito, passou de $1,0 \mathrm{~m}$. que era para 0,5 ; pois a população enorme de fitoplancton que ali evoluiu era verde, e foi o "pasto" alimentador dos ostracodos. Houve um fenômeno paradoxal: após numerosos dias de sêca caiu uma grande chuva em 6 de Junho - as 
águas da cisterna aumentaram de salinidade, em vez de abaixar: de 2,1 subiu para 2,3 por mil. O que deverá ter sucedido foi - a primeira chuva lavou todas as terras contìnuadamente empapadas de água do mar, cuja evaporação dava origem a algum sal sêco espalhado pelo manguesal; na primeira chuva êste sal foi ao lençol subterrâneo que banhava a cisterna. Quando as chuvas foram tantas que já haviam carregado todo o sal, passaram a diluir, e já em 14 de Junho havia mortandade de ostracodos pois a clorinidade baixara a 1,9 , e mais 4 dias depois com mais 4 chuvas caíra a 1,1 por mil, meio imcompatível com os ostracodos Spirocypris desta cisterna, cuja mortandade não foi causada por fenômenos sulfídricos (não houve alteração no metabolismo dos sulfatos, cujas doses eram proporcionais ás diluições) mas houve fenômenos de hipotonia.

\section{FUNDO DA CISTERNA}

O fundo da cisterna é pois de origem heterogênea; inorgânicamente é formado por terra de barreira, de origem geológica terciária, que é a do próprio terreno em que foi cavada a cisterna. De origem extranha temos: inorgânicamente argila trazida por chuvas, pedaços de tijolos e de reboco que desabaram das paredes da cisterna e que já estão em plena desagregação dando areia, terra, e cal; matéria orgânica tudo o que traz a chuva - pedaços de árvores, fôlhas, capim, fôlhas de jamelão e de mangueira que são as árvores que ficam sombreando a cisterna. De origem endogenética, proviniente da própria biocenose da água - detritos das plantas aquáticas: Anacharis canadensis e Lemna minor e dos animais microscópicos e macroscópicos cadáveres de peixinhos, de rãs, de moluscos Lymnaea, de aves como urubús, que estão em decomposição desde 1938 até 1952 . Êste material acumulado forma uma massa mole, pastosa, castanha quasi negra, de um tipo de Dy, mas ainda sem um nome na classificação limnológica dos solos sub-aquáticos. Naturalmente terá provisoriamente nome primeiramente descrito na literatura hidrobiológica: fundo de tipo da cisterna do Pinheiro. Futuros dados de estudos do solo ajuntarão a estes estudos de população e de aguas para que se possa entrar nas "Chaves de Classificação dos Bentos" das limnologias classicas.

A associação epitmênica que se desenvolve no fundo recobrindo os sedimentos é constituída por diatomáceas que trataremos em breve.

A figura 8 mostra a draga de Petersen trazendo do fundo da cisterna uma quantidade de fôlhas mortas e já em decomposição. Atualmente em 1952, o fundo de fôlhas acamadas mede $0,40 \mathrm{~m}$.

\section{DIATOMÁCEAS DO FUNDO}

As diatomáceas do Rio de Janeiro foram descritas em 1851 por Ehrenberg, e também por ZeLLERS em 1867-1877 no "Algae brasiliensis" partícula XXII. A obra mais extensa, a de Zimmerman de 1914-1919, contém uma lista de muitas espécies do Rio de Janeiro. Em 1940 e 1941 
PATRICK descreve várias espécies novas de diatomáceas brasileiras. Embora não podendo fazer a especialidade de diatomista temos necessidade sempre de estar lidando com estas algas, pois estão presentes permanentemente em quasi todos os corpos de águas. Para que não venha futuramente haver alguma dúvida quanto a determinação do nosso material, vamos expôr em forma de uma chave simples como foram tais plantas determinadas com característicos específicos: Diatomáceas raphideas, de valvas dissemelhantes, cuneiformes (Gomphonemadas), com uma valva naviculoide, assimétrica, com uma das extremidades mais estreita que a outra e cuneiforme (nunca com a face de sutura curva .... gênero GOMPHONEMA Ag. (Grupo Assymétrica - os dois lados das valvas não são semelhantes).

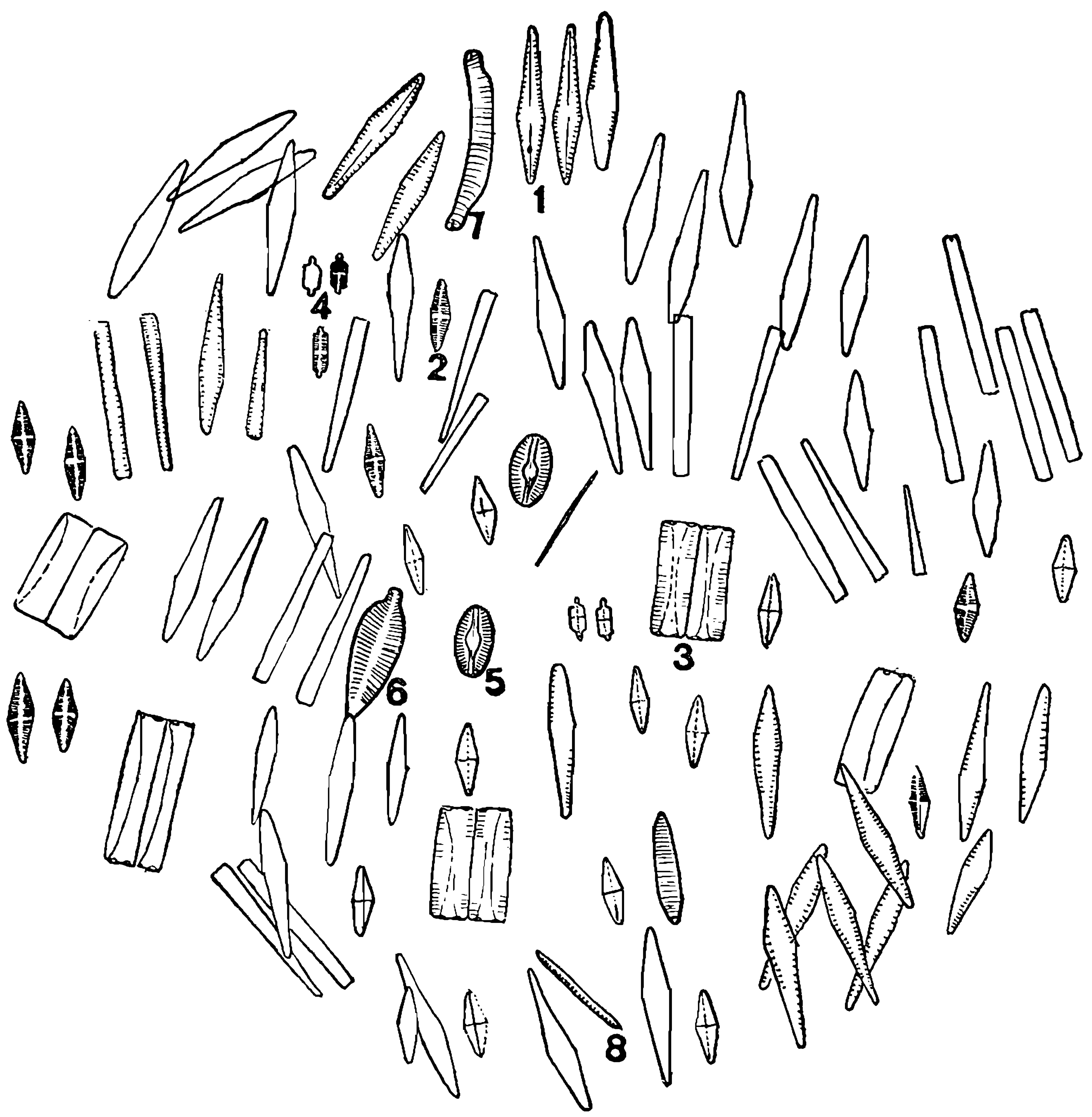

Figura 13 - fórmula diatomística, estão desenhadas 100 diatomáceas nas suas respectivas proporções. 
"Estrias medianas não são alternativamente longas e curtas, mas são estrias iguais. Não há área central hialina. Não há figura em cruz, estauriforme, Valva não lanceolorostrada, extremidade superior não apiculada, a parte mediana não é inchada: 1/ valva cuneiforme e mais ou menos triondulada: G. montanum; 2/ valva cuneiforme não triondulada: GOMPHONEMA BRASILIENSIS Grun.

No Atlas de Schmidt ha a forma Demerarae de 77 por 11 micra, a da nossa cisterna não corresponde a esta forma e além disso tem 40 por 7 micra (fig. $13, n .^{\circ} 1$ ). Ela deverá ser uma espécie ou variedade nova, mas não estamos em condições de estudá-la. Ela passa a predominar no fundo quando a clorinidade mantém-se a 2 por mil (depois de 29 de Maio) no mesmo habitat dos Spirocypris, aos quais servem de alimento. Diatomáceas naviculadas, de valvas semelhantes, divididas simètricamente pela rafe, nódulo mediano ausente, ou quando presente igualmente afastado de ambas as extremidades. Frustulas livres ou unidas em pequeno número. Rafe reto, com 3 nódulos, o do meio transversamente dilatado em cruz, transformado em estauro: gênero ST AURONEIS Ehrg. Espécies de Stauroneis encontradas nas águas da cisterna:

Valvas de bordos não triondulados

$7 \ldots . .$. valvas de extremidades atenuadas rostradas, 1 e $1 \mathrm{a}$

$$
\text { S. anceps Ehr. }
$$

$\left.{ }^{*}\right) \ldots \ldots \ldots$ valvas de lados paralelos, variedade linearis Kuetz.

$$
\text { (fig. 13, n. }{ }^{4} \text { ) }
$$

1a ........ valvas de extremidades não rostradas, estauro estreito, valva curta ligeiramerite lanceolada: $S$. salina W. Sm.

NOTA - a forma típica de $S$. salina tem 50-60 micra por 5 micra, tem 18 estrias em cada 10 micra. Esta espécie aqui da cisterna tem 19 estrias em cada 10 micra, e mede desde 20 por 6 micra, até 28 por 7 micra.

$$
\text { (fig. 13, n.o 2) }
$$

Outra diatomácea: fig. 13 n. ${ }^{\circ}$. Cocconeide de valvas dissemelhantes, uma só das valvas possue o nódulo mediano, valva largamente oval. Valva sem estrias marginais, rafe mediano partindo a valva em duas metades simétricas, valva simples, a superior só é que é pseudo-rafe, a inferior com nódulos: gênero COCCONEIS. A espécie vista por nós na cisterna concorda com a figura 30 da Pl. 70 do Atlas de Schmidt: Cocconeis forcipata Grev. A variedade que nós encontramos na cisterna tem 13 estrias em cada 10 micra, e o pseudórafe se alarga na região mediana, em vez de se estreitar como na forma típica de forcipata. 
A diatomácea NITZSCHIA era a que tinha frustula com carenas de grandes pontuações, e opostas diagonalmente ás valvas; valvas não arqueadas nem rostradas, era do grupo linearis, cujas valvas não tem sulcos, a carena é um pouco excêntrica, os pontos carenais são um pouco arredondados ou angulosos, um pouco alargada transversamente, face conexiva reta por vêzes estreitada na parte mediana. A espécie com que mais concordou foi a Nitzchia vitrea Norman; contudo sua forma não coincidiu totalmente com a forma típica, a nossa diferia no seguinte: tinha 11 pontos carenais, e 21 estrias em cada 10 micra. Chama-la-emos nêste trabalho de Nitzschia vitrea identificada para uso ecológico, ou uso limnológico, até que um diatomista sistematista, especialisado neste assunto, a determine após os necessários estudos em culturas puras.

No bentos da cisterna em 29 de Maio entre as fôlhas mortas e no barro do fundo havia a seguinte fórmula diatomística:

1. Gomphonema brasiliensis .... 57\%

2. Stauroneis salina ......... 20\%

3. Fragillaria sp. ........... $10 \%$

4. Stauroneis anceps linearis .... $8 \%$

5. Cocconeis forcipata ......... $2 \%$

6. Gomphonema acuminatum .... $1 \%$

7. Eunotia trigibba .......... $1 \%$

8. Nitzschia vitrea .......... menos de $1 \%$

Os números de 1 a 8 indicam a predominância, e indicam o número destas diatomáceas no quadro da figura 13.

O fundo da cisterna quando na sua fase oligohalina é um GOMPHONEMETUM que persistiu mesmo após a invasão sulfídrica.

Em 3 de Junho, já em outra fase com bôa produção de Ostracoda, ainda havia predominância do GOMPHONEMA, mas a Stauroneis cessa como sub-dominante, cedendo o lugar ao Cocconeis.

\section{FÓRMULA DIATOMÍsTICA}

Gomphonema brasiliensis ....... $62 \%$

Cocconeis forcipata ............ 16\%

Fragillaria ................ $5 \%$

Cymbella minium ............. $2 \%$

Stauroneis salina .............. $2 \%$

Stauroneis anceps linearis ....... $5 \%$

Gomphonema acuminatum ........ $5 \%$

Eunotia trigibba ............. $1 \%$

Nitzschia vitrea .............. $1 \%$

indeterminado .............. $1 \%$ 


\section{LIMNOLOGIA EXPERIMENTAL}

Para melhor observação dos sêres das águas da cisterna, fizemos as seguintes experiências, colocamos todo o material: planctonico, bentônico e de película em vazos de 4 litros, de vidro branco, com as diferentes adubagens:

\section{NEIO I}

Nitrato de potássio $1 \mathrm{gr}$. L.

Fosfato dipotássico ............. $200 \mathrm{mg} . \mathrm{L}$.

Cloreto de cálcio ................ $100 \mathrm{mg} . \mathrm{L}$.

Cloreto de ferro ............... $1 \mathrm{mg} . \mathrm{L}$.

Sulfato de magnésio .............. $10 \mathrm{mg} . \mathrm{L}$.

Nitrato de cálcio ............... $100 \mathrm{mg} . \mathrm{L}$.

MEIO II

Água da cisterna adubada com nitrato de potássio a $0,1 \%$

MEIO III

Água da cisterna mais:

Nitrato potássio

$1 \mathrm{gr}$. L.

Fosfato dipotássico

$250 \mathrm{mg} . \mathrm{L}$.

Cloreto de cálcio ............... $100 \mathrm{mg} . \mathrm{L}$.

Nitrato de cálcio .............. $100 \mathrm{mg} . \mathrm{L}$.

Cloreto de ferro ................ $1 \mathrm{mg} . \mathrm{L}$.

MEIO IV

Nitrato de amônio ............. $200 \mathrm{mg} . \mathrm{L}$.

Fosfato de potássio .............. $100 \mathrm{mg} . \mathrm{L}$.

Cloreto de cálcio .............. $100 \mathrm{mg} . \mathrm{L}$.

Cloreto de ferro ............... $1 \mathrm{mg} . \mathrm{L}$.

Sulfato de magnésio ............ $100 \mathrm{mg} . \mathrm{L}$.

(assemelhando ao Meio de Benecke, nitro-amoniacal)

MEIO V

Água da cisterna ............... 1/3

água da chuva recolhida em vidro .... $2 / 3$

$\mathrm{pH}=5,3$ acertado com ácido nítrico puríssimo.

Fosfato potássico .............. $100 \mathrm{mg} . \mathrm{L}$.

Cloreto de ferro ............... $1 \mathrm{mg} . \mathrm{L}$. 
MEIO VI

(meio não cálcico, amoniacal)

Nitrato de amônio

$1 \mathrm{gr}$. L.

Fosfato de potássio ............. $200 \mathrm{mg} . \mathrm{L}$.

Sulfato de magnésio ............. $100 \mathrm{mg}$.L.

MEIO VII

Água da cisterna

com Nitrato de amônio ........... 200 mg.L.

(meio nitro-amoniacal.)

MEIO VIII

Nitrato de cálcio

$100 \mathrm{mg} . \mathrm{L}$.

Nitrato de potássio

$25 \mathrm{mg} . \mathrm{L}$.

Fosfato monopotássico .......... $250 \mathrm{mg} . \mathrm{L}$.

Cloreto de ferro .............. $1 \mathrm{mg} . \mathrm{L}$.

Carbonato de potássio ........... $34 \mathrm{mg} . \mathrm{L}$.

Sulfato de magnésio ............ $25 \mathrm{mg} . \mathrm{L}$.

(assemelhando-se ao meio de Uppens)

\section{MEIO IX}

(meio super-cálcio)

Nitrato de potássio ............ $200 \mathrm{mg} . \mathrm{L}$.

Fosfato de potássio ............ $20 \mathrm{mg} . \mathrm{L}$.

Cloreto de cálcio ............. $2 \mathrm{gr} . \mathrm{L}$.

Cloreto de ferro .............. $5 \mathrm{mg} . \mathrm{L}$.

Sulfato de magnésio ............ $10 \mathrm{mg} . \mathrm{L}$.

MEIO X

Água da cisterna em

Nitrato de sódio .............. $100 \mathrm{mg} . \mathrm{L}$.

Fosfato de sódio ............. $20 \mathrm{mg} . \mathrm{L}$.

Cloreto de ferro .............. $1 \mathrm{mg} . \mathrm{L}$.

(análogo ao meio de Schreiber)

Em todos os meios foram acrescentados os seguintes fatores: Cloridrato de tiamina ....... $1 \mathrm{mg}$.; Riboflavina ......1 $\mathrm{mg}$. ; cloridrato de pirodoxina ......1 $\mathrm{mg}$.; Nicotinamida ..... $50 \mathrm{mg}$.; Ácido pantotênico . ......25 mg.; $0,003 \%$, acetato de potássio . ..... $0,0003 \%$ acetato de potássio . . . . . . 0,0003\% óxido de zinco . . . . . . . traços; cloreto de manganez .. traços. 
Uma das razões de colocarmos peptona nestes meios de cultura foi haver substâncias orgânicas em dissolução nas águas da cisterna (reparemos que o oxigênio consumido nas várias dosagens estava de 1,0 a 4,0; e no dia 19 de Junho de 1952 a $5,2 \mathrm{mg} \mathrm{1.)}$. O que se pode conceber é que tenha havido o seguinte: as carnes dos vários animais lá se decompuzeram, assim produziram uma pequena quantidade de proteínas, de polipetídeos, de amino-ácidos, de peptonas que era usada em parte para a nutrição das algas e protozoários. Mas cremos que o teor não poderá chegar a $0,2 \%$ de peptona (como é o teor ótimo aconselhado por Pringsheim para cultura de algas). O extrato de concentração equivalente ótimo para algas é na porcentagem de 0,05 até $0,5 \%$, assim para ter o teor mínimo seria necessário que a nossa cisterna de 10.000 litros de água, tivesse um extrato de 50 quilos de carnes de animais; como isto ainda não aconteceu, embora tivesse caído uma porca na cisterna que pesava 60 quilos, mas esta não chegou nem mesmo a morrer, porque foi retirada no mesmo dia. Contudo o maior animal que lá caiu e apodreceu foi um urubú que pesava talvez tanto quanto uma galinha, o que daria $0,03 \%$ de carne, já razoável quantidade para influir na biocenose da cisterna.

Como êstes meios de cultura foram principalmente enriquecedores de protozoários, daremos uma chave simples, dedicada a limnologista, para as poucas espécies destas águas oligohalinas.

\section{RECONHECIMENTO DOS PROTOZOÁRIOS DAS ÁGUAS DA CISTERNA DO PINHEIRO}

ORDEM HYPOTRICHIDA Stein

Com cílios e cirros: família OXYTRICHIDAE Kent.

Encontramos desta família o gênero

STYLONICHYA Ehrenberg. Corpo não flexível, ovóide ou reniforme; superfície ventral lisa, dorsal convesa, peristoma largo estreitando até ao meio do corpo, do tipo triangular; cirros: 8 frontais, 5 ventrais, 5 anais.

Para determinação do animal a que referimos nas águas do poço da Ilha do Pinheiro:

1. - Peristoma normal (não do tipo subgen. HISTRIO): subgênero Stylonichia .................. 2 (fig. 14, n. $\left.{ }^{\circ} 6\right)$ :

2. - corpo mais largo anteriormente que posteriormente; posteriormente em quilha ..................... mytilus corpo ovoide, terminando oviforme, com cistos esféricos ......

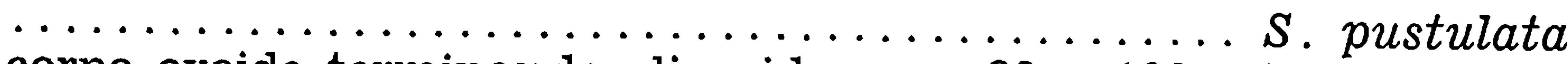
corpo ovoide terminando elipsoide, com 80 a 100 micra de comprimento, não tendo 3 cerdas longas caudais, mas tendo 5 ou mais de 5 e não muito longas:.

STYLONICHIA SP. .... da cisterna do Pinheiro.

(fig. 14, n. ${ }^{\circ}$ ) . 


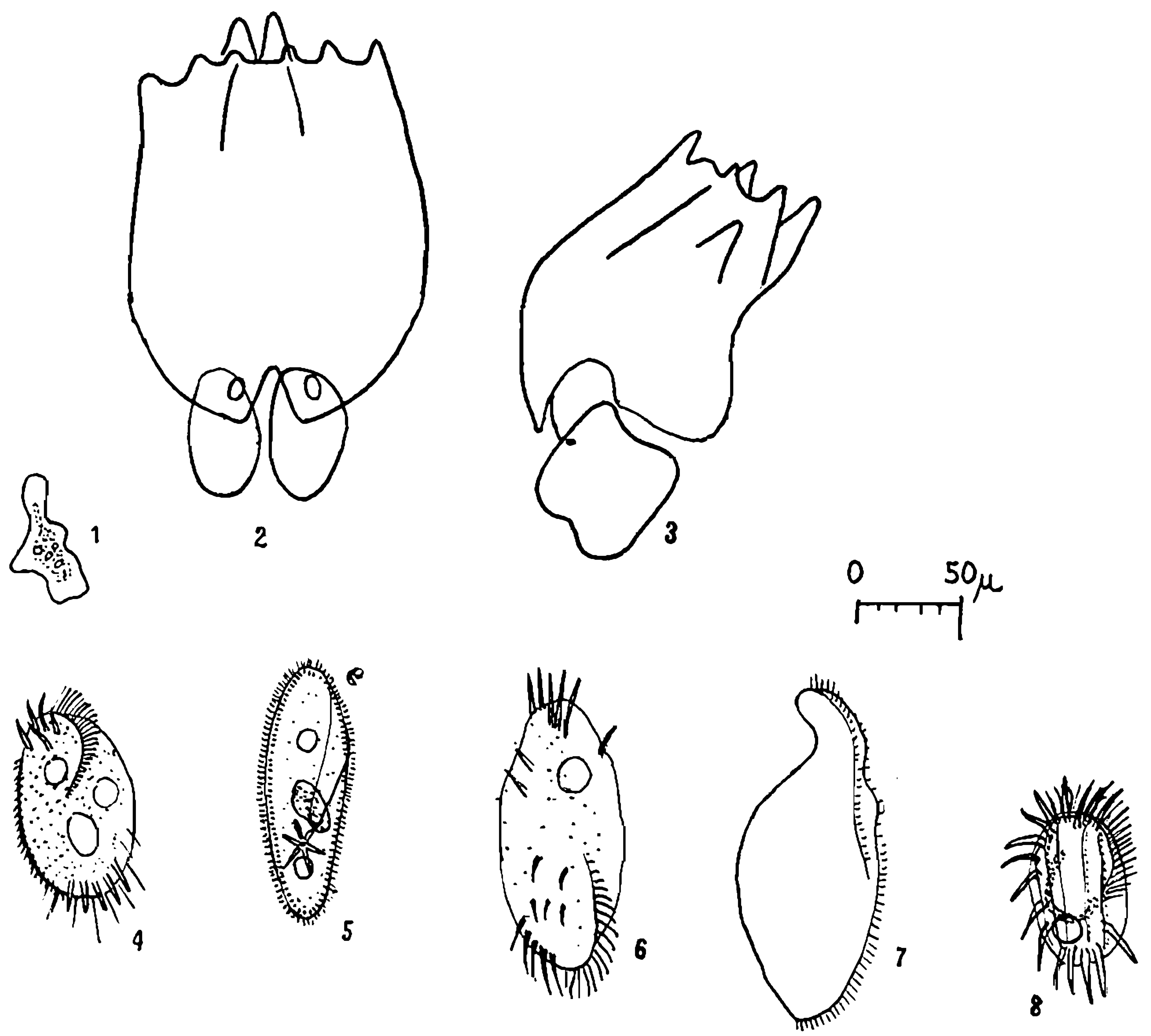

FIGURA 14

n. $.^{\circ} 1-$ Amoeba sp.

n. ${ }^{\circ} 2$ - Brachionus sp. (rotífero) e n. ${ }^{\circ} 3$ Protozoários:

n. 4 - Pleurotricha sp.

n. 5 - Paramecium sp.

n. 6 - Stylonichia sp.

n.o 7 - Amphileptus sp.

n. 8 - Euplotes charon

HYPOTRICHIDA sem cílios, sòmente com cirros: cirros frontais, ventrais, anais e marginais: família EUPLOTIDAE Claus. Corpo ovoide inflexível, superfície ventral lisa, dorsal convexa, com listas longitudinais, peristoma largamente triangular, ou em forma de harpa. Cirros 9 ou mais fronto-ventrais, 5 anais, 4 caudais esparsos. Macro e micronúcleo em faixa. 1 vacúolo contratil. Incolor ou verde por zoochorela: EUPLOTES Ehrb.

Arredondado anteriormente $\ldots \ldots E$. charon (Mueller) (fig. 14, n. ${ }^{\circ} 6$ ) Em quilha anteriormente ....... E. patella (Mueller) 


\section{OXYTRICHIDAE:}

gênero PLEUROTRICHA Stein - corpo oblongo com extremidades arredondadas. As fileiras de cílios marginais são contínuas, 5 a 8 cirros frontais, ventrais, ventrais arranjados em 2 ou mais carreiras irregulares, as carreiras internas tem menos cirros que as externas, cirros anais 5 ou 6, 2 sendo mais próximos da margem posterior. Movimento rápido quasi pulando, guinando para a direita e para a esquerda.

1 . - corpo em forma de lanceta :.... (+)

1a. - corpo elipsoide ..... 2

2 . - cirros ventrais em forma de gancho ............ grandis

- cirros ventrais comuns .... PLEUROTRICHA SP. ... da cisterna da Ilha do Pinheiro. (fig. 14, n..$^{\circ} 4$ )

HOLOTRICHIDA: fam. Tracheliidae Kent; corpo em forma de garrafa, parte anterior com uma proboscida aparentemente, na base da qual está situado o citostoma. 1 ou vários vacúolos contrateis. Um ou dois macronúcleos.

AMPHILEPTUS Ehrenberg. Amphileptus sp. ..., da Cisterna do Pinheiro (fig. 14, n. ${ }^{\circ}$ ); de 160 micra por 60 micra.

\section{HOLOTRICHIDA fam PARAMECIDAE Grobben}

Genero PARAMECIUM Em forma de charuto, circulares ou elipsoides em seção transversa. Um macronúcleo 1 ou vários micronúcleos. Peristoma longo e largo. Flexíveis. 2 vacúolos. Sistema irradiante. Movimento irregular, vivo.

Na Ilha do Pinheiro: PARAMECIUM SP. ...; de 80 micra de comprimento. (fig. 14, n. ${ }^{\circ}$ )

O surto espontâneo de protozoários, de rotíferos, e de outros sêres nas águas da cisterna é muito pequeno; para poupar um trabalho grande de captura, passamos a acrescentar nas águas alguns elementos nutritivos, assim, por exemplo, um Paramecium que existe em quantidade mínima, passa a aparecer em grandes quantidades na cultura em laboratório.

O MEIO I, êste meio foi feito como se fôsse o meio de Knopp para cultivo de algas, mas colocamos muito menos magnésio, sòmente deixando os sais que são úteis na nutrição destes vegetais. Nos primeiros dias apareceu uma película superficial que em semana já era muito grossa, cheia de Paramecium e com numerosas Pleurotricha grandis. Nas raízes de Lemna a quantidade de Vorticella era enorme. Os Gomphonema brasiliensis cresceram bem assim como os rotífera do gênero Monostyla e vários protozoa Actinophys sol foram encontrados. Estava em fase B-meso-saprobia. Êste meio não foi favorável nem ao crescimento dos copepodas, nem aos dos moluscos; as Lemna e Elodea morreram, ficaram castanhas, caíram no fundo. Ao fim de 5 meses é que houve um surto de Ostracoda, isto é, quando o meio já estava pela me- 

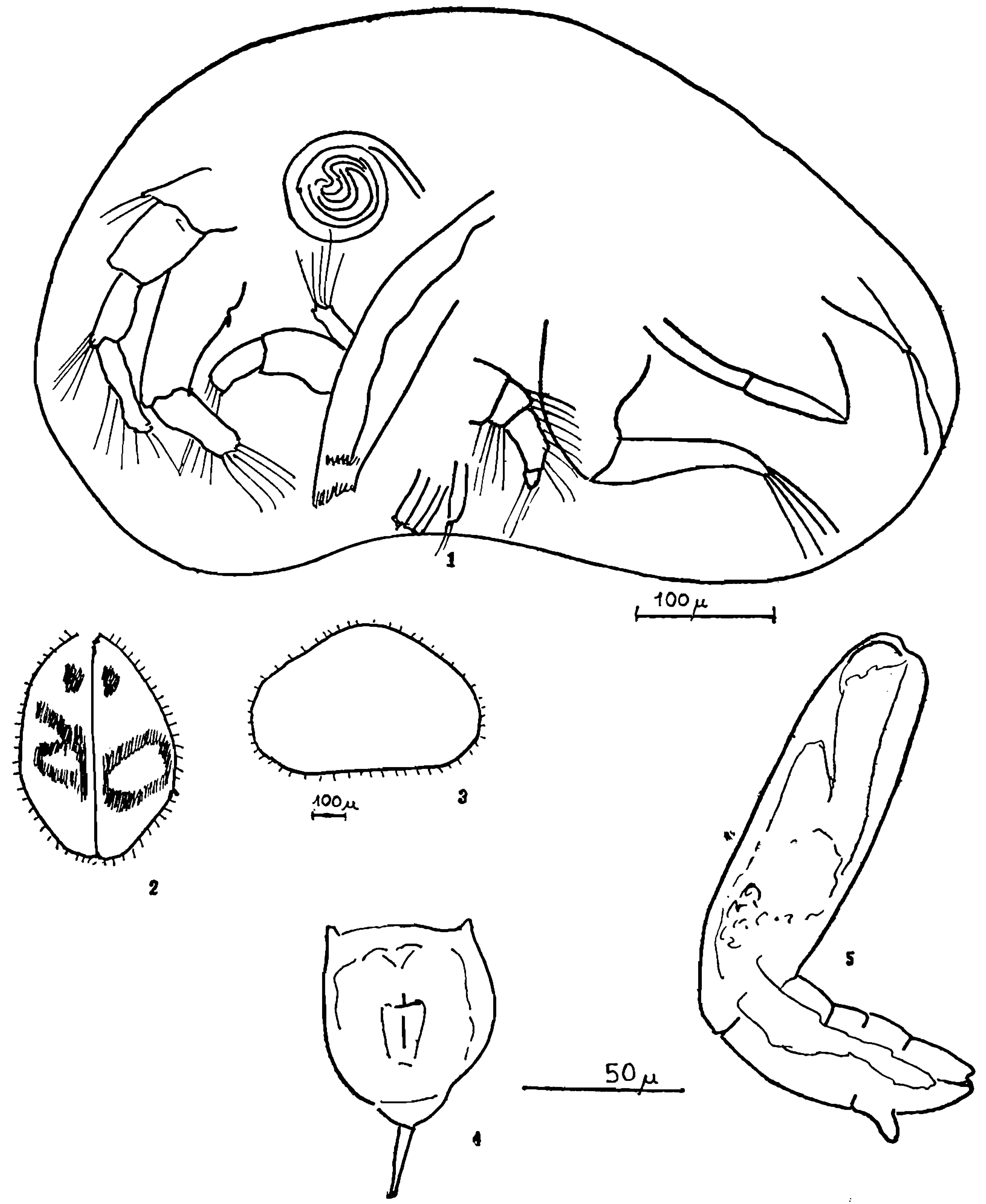

FIGURA 15

n. ${ }^{\circ} 1,2$ e 3 - ostracodo Spirocypris $\mathrm{sp.}$

n. ${ }^{\circ} 4$-- rotífero Monostyla sp.

n. 5 - rotífero Diglena $\mathrm{sp}$. 
tade devido a evaporação, e tudo estava de côr castanha, inclusive a côr das águas que era amarelo - acastanhado - burel" côr 336 C.U.C.".

MEIO II - é apenas uma adubagem nitratada para as plantas. Deu uma leve película de Paramecium, e depois êstes misturados com Brachionus um rotífero. As plantas Elodea e Lemna não morrem, mas também não crescem, ficam como uns fiapinhos na água, depois de 5 meses caem no fundo; nesta ocasião encontram-se larvas de Chironomídsos e muita Vaucheria sp. (uma alga sifonada).

No início o meio estava B-meso-saprobio, depois de alguns meses passou para um grau de podridão maior: A-meso-saprobio.

MEIO III - é uma adubagem nitro-fosfo-cálcica onde se desenvolveu muito bem as esquizofíceas, a as vorticellidae nas raízes de Lemna. No fim de 5 meses o fundo é todo preto, ou melhor verde-escuro, ás águas transparentes com pouquíssimas Lemna vivas, mas estas em pobre estado de desenvolvimento. As Elodea morriam.

MEIO IV - é um adubo nitro-amoniacal semelhante ao meio de Benecke. No começo houve película com abundantes Pleurotricha em desenvolvimento intenso. Houve um desenvolvimento de Elodea, e principalmente mais intenso o das Lemna, que ficaram com fôlhas grandes, mais largas que o comum, e cobriram toda a superfície das águas. É o meio ótimo para as Lemna, para as algas heterocontadas Tribonema. Os moluscos Lymnea nasceram, cresceram e se reproduziram muito bem nêste meio B-meso-saprobio.

MEIO $\mathrm{V}-$ meio ácido, com $\mathrm{pH}=5$. Nada se desenvolveu, nem mesmo as esquizofíceas. Desde o começo deu uma película de numerosos cogumelos, entre eles vimos os Fusarium. Todas as diatomáceas, todas as Lemna, Elodea morreram. Apareceram muitos aneis, véus, películas, e depósitos de cogumelos. É um meio péssimo em que nenhum dos sêres que normalmente vivem na cisterna desenvolvem, tudo aí morre.

MEIO VI - é um meio amoniacal sem cálcio. No começo há um desenvolvimento de diatomáceas do gênero Synedra e depois do ciliado Euplotes charon e Amphileptus. As Elodea, Lemna, os ostracodos e os copepodos desaparecem formando um amontoado de cadáveres no fundo, dando uma decomposição A-meso-saprobio.

MEIO VII - as águas sempre se mantiveram claras, os ostracodos se desenvolvem escassamente, na película houve no comêço algumas amebas. O aspecto é pobre em comparação com o meio IV. O teor de saprobidade era B-meso-saprobio.

MEIO VIII - no início muitas diatomáceas, os protozoários Stylonichia predominaram nestas películas. Depois tudo foi ficando cada vez menor, e com pouco desenvolvimento: as elódeas e as Lemna viveram, mas muito pequeninas, embora muito verdes. 
MEIO IX - formou película fina a princípio, com predominância de Prorodron, um protozoário ciliado. As diatomáceas Stauroneis chegaram a um exuberante desenvolvimento. Alguns Actinophrys flutuavam nas águas. As Lemna ficaram viçosas, mas não tão grandes como as do meio $\mathrm{V}$, nêste meio IX elas tiveram fôlhas muito pequenas; as elódeas Anacharis é que ficaram no máximo de viço e desenvolvimento, e mesmo de maior tamanho e grossura do caule. Não houve contudo desenvolvimento de moluscos nêste meio que estêve em grao A-meso-saprobio.

MEIO X — No comêço a película formada foi muito grossa, com numerosas amebas e seus quistos, mitos Actinophrys sol e muitas Vorticella entre os Rotífera do gênero Diglenea. No fundo as diatomáceas Gomphonema e Fragilıaria cresceram exuberantemente. No fim de 5 meses aparecem as Vaucherias assim como também alguns Gastrotricha-

Depois tudo morre, aparecem vermes de vida livre, e ficam vivas as diatomáceas e as Vaucheria nêste meio A-meso-saprobio.

Notemos que não se viu nada de insetos, pois toda a ilha do Pinheiho (laboratórios, poços, viveiros, etc...) foi intensamente dedetisada, para evitar desenvolvimento do mosquito da malária, o Anopheles tarsimaculatus.

Pelo exame das películas de uma semana já se pode tirar alguma conclusáo sôbre as diversas condições salinas nos meios e o desenvolvimento dos protozoários: notamos que as Vorticella só apareceram e cresceram nas águas da cisterna quando adubadas com um pouco de nitrato, de fosfato e nos meios em que havia cloreto de sódio, magnésio, e tendo as raízes de Lemna como suporte. Mas o Paramecium aparecem e crescem bem sem o magnésio e sem o cloreto de sódio (meio I), assim como as Pleurotricha, sendo que estas näo são tão exigentes já que crescem em meios até com $200 \mathrm{mg}$. 1. de nitrato us amônio, não crescendo contudo nos meios mais salobros, com mais magnésio e mais cloreto de sódio. Nos meios mais amoniacais desenvolve-se o Euplotes charon junto ao Amphileptus que tolera até $1000 \mathrm{mg} .1$. de nitrato de amônio, mas nesta porcentagem já tão alta não se desenvolve mais a Pleurotricha. As Stylonichia não toleram bem as águas desta cisterna, elas dão melhor em águas com pouco dos outros sais (meio VII). Nos meios supercálcicos achamos os Prorodron logo nas películas ue 1. a semana. As elódeas Anacharis canadensis são plantas de águas calcáreas, muito se desenvolveram no meio supercálcico (Meio IX).

\section{SAPROBIDADE DAS ÁGUAS DA CISTERNA}

Para assinalar o grau de podridão em que se acham as águas da cisterna usamos os sêres vivos indicadores que comprovam as saprobias. As águas da cisterna permanecem em fase de B-meso-saprobidade.

Os sêres indicadores que comprovam tal estadio de decomposição foram: os protozoários Euplotes charon, as cianofíceas Oscillatoria, os rotíferos Brachionus. Éste é o grau mais fraco de água mesosaprobia. 
Os moluscos do gênero Lymnaea, que foram até hoje estudados, vivem em águas oligosaprobias ou B-meso-saprobias. Não foram encontrados nunca em águas polisaprobias. As espécies de Lemna vivem bem em águas B-meso-saprobias, assim como as diatomáceas Fragillaria, os ostracoda Spirocypris e o rotífero Monostyla. As Vaucheria que aparecem rara e escarçamente nas águas da cisterna, no meio de cultura cresceram bem quando êste estava A-Meso-saprobio, o mesmo se deu com as Synedra ulna. Outros animais que possívelmente estavam em "estádio potencial" nas águas da cisterna, pois que por exame direto nelas não foram encontrados foram: os Prorodron, os Amphileptus, e os Paramecium, sómente aparecendo em culturas quando estas estavam em podridão A-Meso-Saprobia.

As espécies da cisterna são oligohalobias a 2 por mil de cloretos. Nunca vimos as águas da cisterna ficar mais podres (A-Meso-Saprobias) ou ficar mais depuradas (oligosaprobias) desde que viemos á ilha, isto é, desde 1938 .

\section{PEIXES}

Os peixinhos Lebistes reticulatus Peters foram introduzidos pela Rockfeller Foundation, como peixes larvofagos, considerados muito úteis para a diminuição do número de mosquitos aqui entre nós. Estes peixinhos originais da Ilha da Trindade, vieram a ter o tamanho duplo dos originais, a ter côres demasiado vivas e muito variegadas. Compreende-se que seja este peixinho de grande popularidade entre os criadores de espécies ornamentais, pois êle é extremamente fertil, muito ativo, tem uma variedade muito grande de colorido e sobrevivem em águas com falta de arejamento. No aquário êle não foge, não se esconde, não é tímido, amadurece ràpidamente, é sujeito a poucas doenças. Êle tem uma resistência térmica enorme, desde $18^{\circ}$ até $37^{\circ} \mathrm{C}$. mas a zona de conforto está entre $23^{\circ}$ e $28^{\circ} \mathrm{C}$; com forte razão foram êstes porquanto os iniciantes em aquário-técnica sempre tem sucesso com motivos que deram grande desenvolvimento ao "hobby" dos aquaristas; êste peixe. Há muita diferença morfológica entre os machos e as fêmeas; são viviparos. São graciosos, ha os peixinhos brancos, os de côr ambar, pretos, existem os de cauda em lanceta, em leque, os de cauda meio-quadrada, os de cauda em espada simples, em espada de comprimento dobrado, em espada dourada que foram obtidos por esforços artificiais de seleção e cruzamento. Podem ter uma ou duas pintas em locais diversos do corpo, as vêzes 1 , ou 2 ou 3 faixas vermelhas, verdes, azues precaudiais, ou medianas.

Outra vantagem que diminue o trabalho do piscicultor de aquário é que êles podem variar a alimentação sem grande prejuízo; comem tanto daphnias, quanto vários copepodos, larvas de insetos, de crustáceos, de moluscos, que são atirados dentro do aquário com a concha partida, comem minhocas, outras larvas, carne de peixe, etc. Os que capturamos na cisterna tinham: ou nenhuma ou só uma mancha caudal, cauda em leque comum "vira-lata", de côr primeiro azulada, de- 
pois esverdeada. Os nossos comem também as micro-flora e micro-fauna que fica preza nas raízes de Elodea.

\section{BALANÇO DE PRODUTIVIDADE}

Para completar as observações hidrobiológicas resta fazer um balanço quantitativo dos sêres vivos.

A produção encontrada na cisterna foi anualmente $6,4 \mathrm{gr}$. de peixinhos, entre os barrigudinhos comuns e os Lebistes reticulatus. Êstes peixinhos comem como alimento útil copepoda, ostracodos, pequenos moluscos, larvas de insetos, que devem orçar segundo os cálculos dos tratados de piscicultura em dez vêzes o peso dos peixes. A cisterna deverá produzir 320 gramas de alimento inúteis para o peixa. Êste alimento vivo utilisado pelo peixe é nutrido por sua vez direta ou indiretamente pela produção vegetal. A produção vegetal anual foi de:

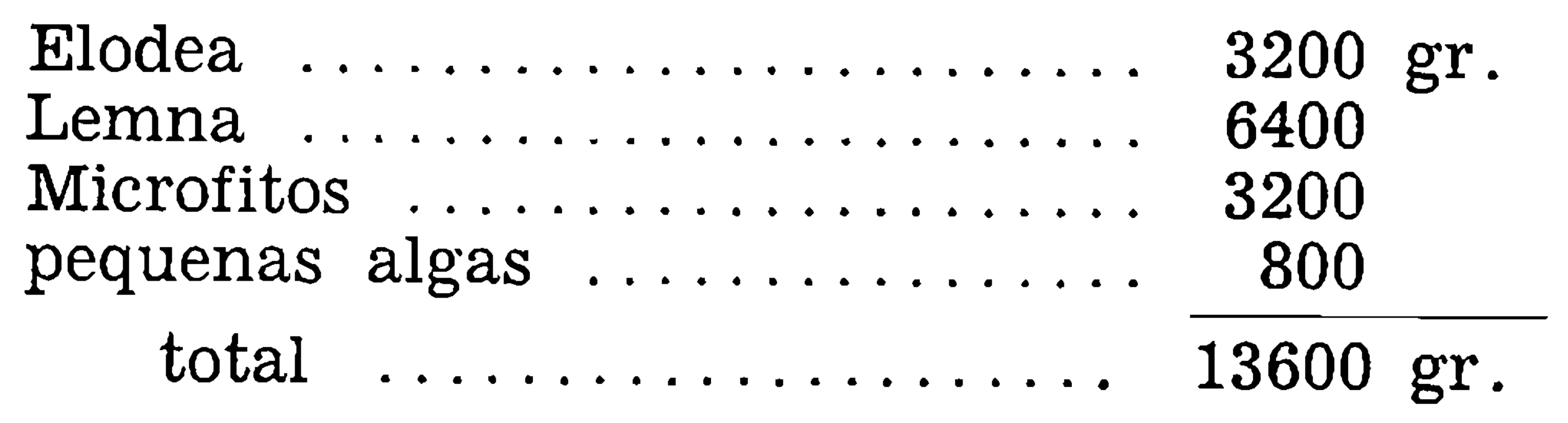

O conjunto que existe de ostracodos, copepodos, larvas pode ser orçado em $384 \mathrm{~g}$. anuais, sendo que dêstes $64 \mathrm{~g}$ deve ser principalmente a comida do Lebistes reticulatus. As outras $320 \mathrm{~g}$. são o peso proprio e o alimento dos moluscozinhos Lymnea que não servem de alimento aos peixinhos quando ficam grandes e de concha mais dura. Estas $384 \mathrm{~g}$. de animaizinhos vivem da produção de $3840 \mathrm{~g}$. de diatomáceas anualmente. A vista do que pudemos observar as diatomáceas do GOMPHONEMETUM parecem desenvolver a razão de 2 miligramas por $\mathrm{cm}^{2}$ por mês, ou sejam 200.000 diatomáceas médias as que crescem por dia, por centímetro quadrado. A superfície do fundo da cisterna sendo de $3,34 \mathrm{~m}^{2}$ deverá dar uma produção anual de $800 \mathrm{gr}$. de diatomáceas conforme verificamos. Para alimentação dos animais necessitam-se mais $3040 \mathrm{~g}$. que se acham na superfície da cisterna cujos $175.000 \mathrm{~cm}^{2}$ dariam para alojar $4.200 \mathrm{~g}$. anuais de diatomáceas, mas usado para crescimento). Nesta explicação não entramos com a produa cisterna só aloja $3040 \mathrm{~g}$. (isto é o $72 \%$ da superfície da cisterna é ção plantônica de diatomáceas, o que daria margem mais favorável ainda a tal produtividade; e, resumindo:

Peixe LEBISTES RETICULATUS, 6,4 g.

Animais usados pelos peixes:

Ostracoda

Copepoda

larvas

$64 \mathrm{~g}$.

Molusca, etc. $1420 \mathrm{~g}$. 
Produção vegetal

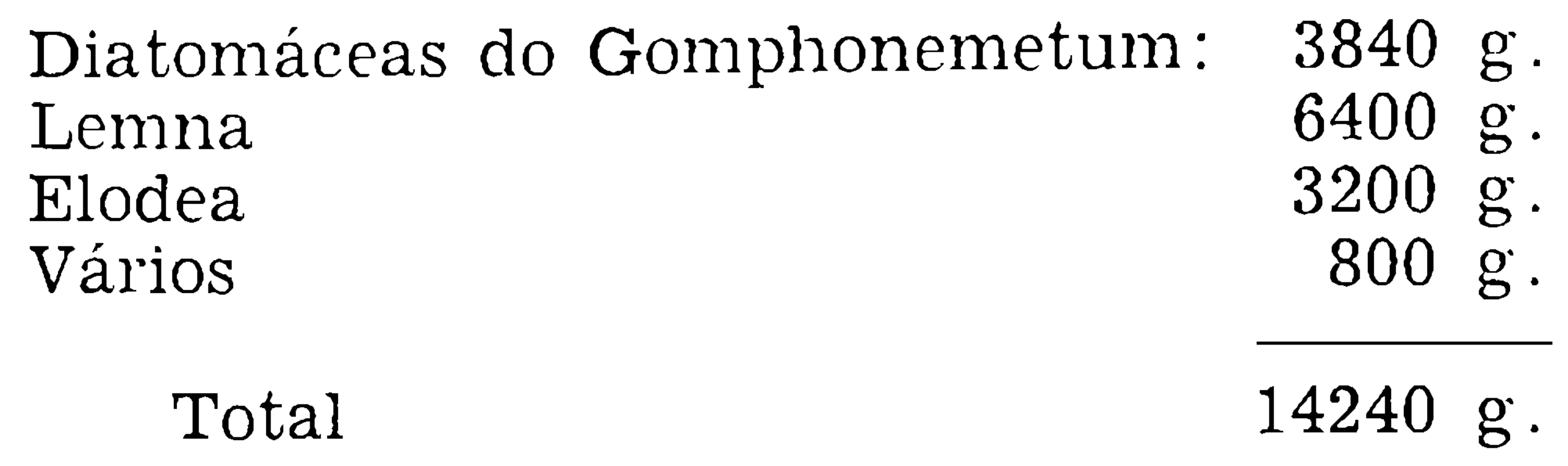

\section{EVOLUÇÃO FUTURA DAS ÁGUAS DA CISTERNA}

Esta cisterna está em fase de aterramento, e vai-se estupindo pelo acúmulo constante de aluviões, pelas fôlhas que caem das árvores, e porque as suas paredes se desfazem pouco a pouco, sem que haja conservação. O seu destino será, se não fôr bem cuidada, o futuro desaparecimento.

Quanto as águas elas deverão passar do atual estádio B-meso-saprobio para um grau mais forte de decomposição, A-meso-saprobio, e depois na fase final o polisaprobio. Se por acaso houver uma muito grande enchente, e enormíssima queda de chuva com inundações, de modo que ela venha a transbordar como aconteceu em 1940, ela reiniciará o seu ciclo novamente: catarrobia - oligosabrobia - mesosaprobia - etc., e naturalmente começará novamente com a fase de água doce, para passar ao regime oligohalino em que se mantém.

Será interessante o Instituto Oswaldo Cruz mante-la em estado de conservação, pois servirá de tema de estudo para os alunos do curso de hidrobiologia, fazendo parte do material escolar. 